ASSOCIATION FOR TEACHER EDUCATION IN EUROPE

Department of Education of the Faculty of

Education and Psychology

The University of Latvia

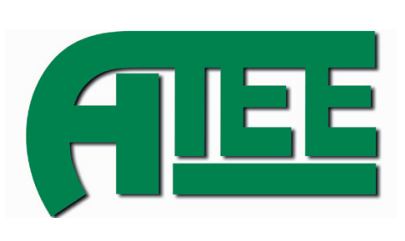

\title{
SPRING UNIVERSITY
}

\section{TEACHER \\ OF THE 21st CENTURY:}

Quality Education for Quality Teaching

May 2-3, 2008 


\title{
Organizing Committee:
}

Indriķis Muižnieks, Pro-rector of the University of Latvia, Chair of the Organizing Committee, Latvia Maureen Killeavy, ATEE, Ireland

Irēna Žogla, Member of the ATEE Administrative Council, Chair, the University of Latvia, Professor, Latvia

Aīda Krūze, Head of the Department of Education, the University of Latvia, Professor, Latvia

Alona Rauckienè, Head of the Department of Education Methodologies, Klaipéda University, Assoc. Professor, Lithuania

Erik de Vreede, ATEE, ATEE-NEWS editor, the Netherlands

Lūcija Rutka, Secretary of the conference, the University of Latvia, Assoc. Professor, Latvia

Zanda Rubene, the University of Latvia, Assoc. Professor, Latvia

Ivars Muzis, Riga Teacher Training and Educational Management Academy, Assoc. Professor, Latvia

Irina Maslo, the University of Latvia, Professor, Latvia

Sarmìte Tūbele, the University of Latvia, Assoc. Professor, Latvia

Emīlija Černova, the University of Latvia, Professor, Latvia

Rudite Andersone, the University of Latvia, Assoc. Professor, Latvia

Tamāra Bogdanova, Riga Teacher Training and Educational Management Academy, Professor, Latvia

Dainuvīte Blūma, the University of Latvia, Professor, Latvia

Chair of the Academic Committee: Dr. Habil. Irēna Žogla, Latvia

\author{
Reviewers: \\ Dr. Habil. Ārija Karpova, Latvia \\ Dr. Lūcija Rutka, Latvia \\ Dr. Riva Levenchuk, Israel \\ Dr. Zanda Rubene, Latvia \\ Dr. Rudīte Andersone, Latvia \\ Dr. Tamāra Bogdanova, Latvia \\ Dr. Habil. Irina Maslo, Latvia \\ Dr. Emīlija Černova, Latvia \\ Dr. Ivars Muzis, Latvia \\ Dr. Iveta Kestere, Latvia \\ Dr. Aīda Krūze, Latvia \\ Dr. Tatjana Kurilova, Latvia \\ Dr. Alona Rauckiené, Lithuania \\ Dr. Rasma Vīgante, Latvia \\ Dr. Sarmīte Tūbele, Latvia \\ Dr. Dainuvīte Blūma, Latvia
}

Reviewed and selected materials of the International Conference - ATEE Spring University "TEACHER OF THE 21st CENTURY: Quality Education for Quality Teaching” are included in this issue for usage in further research, practical implementation and discussion. 


\section{SATURA RĀDĪTĀJS / CONTENTS}

PLENARY REPORTS

NENOZĪMĪBAS ĪPATNĪBAS. PEDAGOĢIJAS VĒSTURE SKOLOTĀJU IZGLĪTĪBĀ

QUALITIES OF IRRELEVANCE. HISTORY OF EDUCATION IN THE TRAINING

OF TEACHERS

Marc Depaepe

TEACHER TRAINING FOR SPECIAL EDUCATION AND INCLUSIVE EDUCATION -

A CONTRADICTION?

VAI PASTĀV PRETRUNA STARP SKOLOTĀJU GATAVOŠANU SPECIĀLAI IZGLĪTĪBAI UN

IEKL,AUJOŠAI IZGLĪTĪBAI?

Thomas Hofsäss

TEACHERS AS RESEARCHERS IN THE ERA OF TESTS

SKOLOTĀJI KĀ PĒTNIEKI TESTU LAIKMETĀ

Irēna Žogla

LIST OF PARTICIPANTS

47

1. DEVELOPMENT OF TEACHERS' PSYCHOLOGICAL COMPETENCE 53

PEDAGOGICAL PSYCHOLOGICAL SERVICES' ACTIVITY IN RESPECT OF TEACHERS 55 PEDAGOĢISKI PSIHOLOĢISKO PAKALPOJUMU DARBĪBA SKOLOTĀJU SKATĪJUMĀ Algirdas Ališauskas

GLOBALIZATION: CHANGE MANAGEMENT AND THE NEW ROLES OF EDUCATORS 62 GLOBALIZĀCIJA: PĀRMAIN̦U VADĪŠANA UN IZGLİTOTĀJU JAUNĀS LOMAS Anita Auzinga

VALUE ORIENTATIONS AS THE BASIS OF THE MORAL QUALITIES OF SENIOR S ECONDARY SCHOOL STUDENTS 69

VĒRTİBORIENTĀCIJAS KĀ VECĀKO KLAŠU SKOLĒNU TIKUMISKO İPAŠĪBU PAMATS Mihail Chehlov

PENSIONĒTO PEDAGOGU DZĪVESDARBĪBAS PRIORITĀTES, PIEŅEMTIE IZAICINĀJUMI UN DOMINĒJOŠIE EMOCIONĀLIE STĀVOKL̨I 73 RETIRED EDUCATORS' PRIORITIES, CHALLENGES AND PREDOMINANT EMOTIONAL STATES IN LIFEACTIVITY

Arija Karpova

PECULIARITIES OF PROSPECTIVE TEACHERS' REFLECTION 83 TOPOŠO SKOLOTĀJU REFLEKSIJAS İPATNİBAS Albina Kepalaitè

LĪDZATKARĪBAS FENOMENA TEORĒTISKIE ASPEKTI 89

THE THEORETICAL ASPECTS OF THE PHENOMENON OF CO-DEPENDENCE

Ilona Laizāne, Lücija Rutka

ADULT LEARNING \& TEACHER'S PSYCHOLOGICAL COMPETENCE 98 PIEAUGUŠO MĀCİŠANĀS UN SKOLOTĀJU PSIHOLOĢISKĀ KOMPETENCE Milena Remis

PEDAGOĢISKĀ PROCESA PSIHOLOĢISKIE FAKTORI 104 PSYCHOLOGICAL FACTORS OF THE PEDAGOGICAL PROCESS 
PEDAGOGA EMOCIONĀLĀS VIDES ORGANIZĀCIJAS NOZĪME UN SPECIFIKA

INTEREŠU IZGLĪTIIBAS IESTĀDĒ

THE IMPORTANCE AND PARTICULARITY OF THE EDUCATOR IN THE ORGANIZATION

OF THE EMOTIONAL ENVIROMENT AT EDUCATIONAL INSTITUTIONS OF INTERESTS

Vladimirs Šibajevs

JAUNO BASKETBOLISTU PSIHOLOĢISKĀS SAGATAVOTĪBAS FAKTORU STRUKTŪRA 126 THE STRUCTURE OF YOUNG BASKETBALL PLAYERS' PSYCHOLOGICAL

PREPARATION FACTORS

Žermēna Vazne, Andris Rudzītis, Viesturs Lārin̄š

PARENTS' AND EDUCATORS' ATTITUDES TOWARD CHILDREN'S NATIONAL IDENTITY ..... 137 VECĀKU UN SKOLOTĀJU ATTIEKSME PRET BĒRNU NACIONĀLO IDENTITĀTI

Vitolda Sofija Glebuvienè, Irena Kapustienè

MĀSZINĪBAS PROGRAMMAS ATTĪSTĪBAS UN REALIZĀCIJAS IZVĒRTĒJUMS 147 EVALUATION OF DEVELOPMENT AND IMPLEMENTATION OF NURSING PROGRAMMES

Tatjana Kokina

MATEMĀTIKAS JĒDZIENI PIRMSSKOLĀ 154 NOTIONS OF MATHEMATICS IN PRESCHOOL EDUCATION

Ata Krūmina, Bronislavs Zeḷcermans

KLĪNISKĀ PRAKSE KĀ NĀKAMO MEDICĪNAS MĀSU APMĀCĪBAS KVALITĀTES

NOSACĪJUMS 159

CLINICAL PRACTICE AS A CONDITION OF QUALITY IN EDUCATION OF NURSES

Jelena Sargsjane

PREPARING KINDERGARTEN TEACHERS FOR THE COMPLEX FIELD

OF EDUCATION 169

PIRMSSKOLAS IZGLĪTĪBAS IESTĀŽU SKOLOTĀJU SAGATAVOŠANA

DAUDZVEIDĪGAM DARBAM

Mirjana Šagud

STUDENTU ADAPTĀCIJA MEDICĪNAS KOLEDŽĀ 176

ADAPTATION OF STUDENTS AT A MEDICAL COLLEGE

Ligita Umbraško

RESEARCH AND IMPROVEMENT OF ONE'S OWN PRACTICE - A WAY TO THE

DEVELOPMENT OF TEACHERS'/PRESCHOOL TEACHERS' PRACTICAL COMPETENCE 184

PĒTNIECĪBA UN PIEREDZES ATTĪSTĪBA - SKOLOTĀJA PROFESIONĀLĀS

KOMPETENCES VEIDOŠANA

Lidija Vujičić

3. CURRICULA DEVELOPMENT FOR THE BASIC AND SECONDARY SCHOOL TEACHER EDUCATION

SOCIĀLĀS PRASMES IZGLİTĪBAS UN MĀCĪBU PRIEKŠMETU PROGRAMMĀS

SOCIAL SKILLS IN THE CURRICULUM

Rudīte Andersone

STUDY SKILLS AS AN INDEPENDENT FACTOR OF CONTENT ACQUISITION

IN THE SECONDARY SCHOOL DISCIPLINE "HISTORY OF CULTURE" 203

MĀCİŠANĀS PRASMES KĀ NEATKARĪGS SATURA APGUVES FAKTORS KULTŪRVĒSTURES KURSĀ VIDUSSKOLĀ

Austra Avotina 
PROFESIONĀLĀS IZGLĪTĪBAS SKOLOTĀJU UN AUDZĒKN̦U SADARBĪBAS KVALITĀTE PROFESIONĀLĀS IZGLĪTĪBAS IESTĀDĒ

THE QUALITY OF CO-OPERATION BETWEEN VOCATIONAL EDUCATION TEACHERS

AND STUDENTS IN A VOCATIONAL EDUCATION ESTABLISHMENT

Ilze Brante

JAUNĀKĀ SKOLAS VECUMA BĒRNU SASKARSMES PRASMJU ATTĪSTĪBAS IESPĒJAS SPORTA DEJU STUNDĀS

FOSTERING JUNIOR FORM STUDENTS' COMMUNICATION SKILLS WITH THE HELP

OF MOVEMENT AND DANCE IN SPORTS DANCE LESSONS

Irina Direktorenko, Ināra Muraško

PROFESIONĀLĀ DARBĪBA UN MĀCIIŠSANĀS MEDICĪNAS JOMĀ (DIAGNOSTISKAJĀ

RADIOLOĢIJĀ) - TĀLĀKIZGLİTİBA UN AR TO SAISTİTĀS PROBLĒMAS

PROFESSIONAL ACTIVITY AND LEARNING IN MEDICINE - POSTGRADUATE

EDUCATION AND RELATED PROBLEMS

Elizabete Kadakovska

AN OVERVIEW OF THE APPROACH TO CONTENT OF LEARNING AND SECOND LANGUAGE INTEGRATION

IESKATS MĀCIIŠANĀS SATURA UN OTRĀS VALODAS INTEGRĒŠANĀ

Diāna Liepa

PĒTİJUMS PAR SKOLĒNU DABASZINĀTNISKĀS INTERESES IETEKMI UZ ZINĀŠANU

UN IZPRATNES LIMMENI ĶİMIJĀ

STUDY OF THE IMPACT OF STUDENTS' INTEREST IN NATURAL SCIENCES ON THE

LEVEL OF KNOWLEDGE AND COMPREHENSION OF CHEMISTRY

Dagnija Cèdere, Daina Možeika

PLAŠA PROFILA DABASZINĀTN̦U PRIEKŠMETU SKOLOTĀJU SAGATAVOŠANAS

PRIEKŠNOSACĪJUMI LATVIJĀ

PREREQUISITES FOR TRAINING VERSATILE TEACHERS OF NATURAL SCIENCES

IN LATVIA

Juris Porozovs, Jēkabs Raipulis, Gunita Praulīte, Jānis Gedrovics, Irēna Krustozolinga

DEVELOPING COMMUNICATIVE COMPETENCE IN ENGLISH AS A FOREIGN

LANGUAGE (EFL) TEACHING/LEARNING PROCESSES IN LITHUANIAN

COMPREHENSIVE SCHOOLS

KOMUNIKATĪVĀS KOMPETENCES VEIDOŠANĀS ANGḶU VALODAS KĀ

SVEŠVALODAS APGUVES PROCESĀ LIETUVAS VISPĀRIZGLĪTOJOŠĀ SKOLĀ

Rolandas Stanionis, Dalia Kiliuvienè

MĀJTURĪBAS UN TEHNOLOĢIJU PRASMES MĀCĪBU PRIEKŠMETU STANDARTĀ

HOME ECONOMICS AND TECHNOLOGIES' SKILLS IN THE SUBJECT STANDARD

Elita Volāne

4. TEACHERS PROFESSIONAL DEVELOPMENT AND RESEARCH

COMPETENCE

TOPOŠO SKOLOTĀJU PROFESIONĀLĀS VĒRTĪBAS

PROFESSIONAL VALUES OF THE FUTURE TEACHERS

Ilze Briška

FOSTER HOME EDUCATORS' AND PRIMARY SCHOOL TEACHERS' PERMANENT

COLLABORATION COMPETENCE IN EDUCATION 309

SĀKUMSKOLAS SKOLOTĀJU UN BĒRNU NAMU SKOLOTĀJU SADARBĪBA

Auksè Grudžinskytè, Šarūnas Litvinas, Jūratė Gelžinienè 
AN INNOVATIVE APPROACH TO STUDIES AT LATVIAN POLICE ACADEMY

INOVATİVA PIEEJA STUDIJU PROCESAM LATVIJAS POLICIJAS AKADĒMIJĀ

Aldona Homicha

STUDENTU MOTIVĀCIJAS VEICINĀŠANA VIZUĀLĀS MĀKSLAS STUDIJĀS

FACILITATING STUDENTS' MOTIVATION FOR VISUAL ART STUDIES

Daiga Kalēja-Gasparoviča

BIOPSYCHOSOCIAL CORRELATES OF TEACHERS' WORK MOTIVATION

SKOLOTĀJU DARBA MOTIVĀCIJAS BIOPSIHOSOCIĀLĀ KORELĀCIJA

Justina Liesiené, Auksè Endriulaitienè

PEDAGOĢISKĀ VIDE KĀ PIRMĀ STUDIJU GADA STUDENTU ADAPTĒŠANĀS

KOLEDŽĀ VEICINĀTĀJA 346

ADAPTATION OF THE FIRST YEAR STUDENTS TO THE PEDAGOGICAL

ENVIRONMENT

Inga Odina

SHOULD THE FUTURE TEACHERS' ENTERPRISE OF FOSTERING NEW PROJECTS

BE A NORM OR AN EXCEPTION TO THE RULE?

("DISCOPROVITA" - TO LEARN FOR LIFE)

VAI TOPOŠO SKOLOTĀJU UZN̦ĒMĪBAI UN PROJEKTIEM VAJADZĒTU BŪT NORMAI

VAI IZN̦ĒMUMAM? (“DISCOPROVITA” - MĀCĪTIES DZĪVEI)

Karine Oganisjana

THE QUALITY OF AIM-SETTING AND ACHIEVED RESULTS IN ENGLISH FOR SPECIFIC PURPOSES (ESP) STUDY COURSE AS REVEALED IN OPINIONS OF LECTURERS

AND STUDENTS 366

LIETIŠĶĀS SVEŠVALODAS KURSA MĒRĶU IZVIRZİ̌̌SNAS UN SASNIEGTO

REZULTĀTU KVALITĀTE STUDENTU UN DOCĒTĀJU SKATİJUMĀ

Ieva Rudzinska

PROFESIONĀLO KOMPETENČU PILNVEIDE DEJU SKOLOTĀJU IZGLİTĪBĀ 374

THE DEVELOPMENT OF PROFESSIONAL COMPETENCES IN THE EDUCATION

OF DANCE TEACHERS

Rita Spalva, Anna Kūkoja

HOW DO STUDENTS DIFFER IN LEARNING STYLES AND ACHIEVEMENTS I

N LANGUAGE LEARNING? 383

KĀ ATŠĶIRAS STUDENTU MĀCĪBU STILS UN VALODU PRASMJU LİMENIS?

Anna Tatarinceva

5. TEACHER EDUCATION FOR MULTICULTURAL SCHOOLS

392

ETNISKĀ KULTŪRA DAUDZKULTŪRU IZGLĪTĪBAS NODROŠINĀŠANAI:

EIROPAS SAVIENĪBAS UN LATVIJAS KULTŪRAS UN IZGLĪTĪBAS POLITIKAS

DOKUMENTU ANALİZE 394

ETHNIC CULTURE FOR MULTICULTURAL EDUCATION: THE ANALYSIS OF LEGAL PROVISIONS ON EDUCATION AND CULTURE IN THE EUROPEAN UNION AND LATVIA

Zenta Anspoka, Gunta Silinga-Jasjukeviča

SKOLOTĀJU DARBĪBA PUSAUDŽU MĀCĪBU DISCIPLĪNAS VEICINĀŠANĀ 404 TEACHERS' ACTIVITIES FACILITATING TEENAGERS' LEARNING DISCIPLINE

Linda Daniela, Daiga Kalninga

GLOBAL EDUCATION: THE INTERCULTURAL ASPECT 415 GLOBĀLĀ IZGLĪTĪBA: STARPKULTŪRU ASPEKTS

Māra Dirba, Jānis Mencis 
SKOLOTĀJU PILSONISKĀ IZGLĪTĪBA ILGTSPĒJĪGAI ATTĪSTĪBAI

CITIZENSHIP EDUCATION FOR TEACHERS FOR SUSTAINABLE DEVELOPMENT

Inese Jurgena

IEKL,AUJOŠAS IZGLĪTĪBAS IZPRATNE LATVIJĀ

PERCEPTION OF INCLUSIVE EDUCATION IN LATVIA

Dita Nīmante

JAUNĀS PAAUDZES MĀCī̌̌SANĀS PAMATSKOLĀ: MĀCİŠANĀS PANĀKUMI

KĀ KVALITATĪVAS PAMATIZGLĪTĪBAS LIKUMSAKARĪBAS

THE NEW GENERATION OF BASIC SCHOOL LEARNERS: ACHIEVEMENTS

IN LEARNING AS REGULARITIES OF QUALITY LEARNING

Liesma Ose, Svetlana Surikova, Andra Fernāte, Linda Daniela, Daiga Kalniña, Irīna Maslo

JAUNĀS PAAUDZES MĀCIIŠSANĀS VEICINĀŠANAS KVALITĀTE PAMATSKOLĀ

QUALITY OF FACILITATING NEW GENERATION LEARNERS' LEARNING

AT BASIC SCHOOL

Daiga Kalninga, Anita Eiholca, Ilze Briška, Sanita Baranova, Līga Āboltinga, Irēna Žogla

JAUNĀS PAAUDZES MĀCĪŠANĀS: KAS KAVĒ PUSAUDŽU MĀCĪŠANĀS

PANĀKUMUS SKOLĀ?

LEARNING OF THE NEW GENERATION: WHAT ARE THE OBSTACLES

TO GOOD LEARNING AT SCHOOL?

Linda Daniela, Svetlana Surikova, Andra Fernāte, Vēsma Priedīte, Karine Oganisjana,

Rudīte Andersone

INTERCULTURAL EDUCATION IN ROMANIAN TEACHING AND LEARNING PROCESS

MIJKULTŪRU IZGLİTĪBA RUMĀNIJAS MĀCĪBU PROCESĀ

Adrian Opre, Liliana Ciascai, Iuliana Marchis, Dana Opre

SKOLOTĀJU GATAVĪBA DARBAM MULTIKULTURĀLĀ KLASES VIDĒ 480

TEACHERS' READINESS FOR WORK IN A MULTICULTURAL ENVIRONMENT

IN THE CLASSROOM

Anita Petere

ENHANCING ETHNIC DIVERSITY - A CHALLENGE FOR TEACHER EDUCATION

IN ESTONIA 487

RESPEKTS PRET ETNISKO DAŽĀDĪBU - IZAICINĀJUMS IZGLĪTĪBAI IGAUNIJĀ

Karmen Trasberg

6. TEACHER EDUCATION FOR SPECIAL SCHOOLS

PREVENTION OF MENTAL ILL-HEALTH AND SUICIDAL BEHAVIOUR IN SCHOOL

BY COUNTERACTING TRUANCY 498

SLIKTĀS GARĪGĀS VESELĪBAS UN SUICIDĀLAS UZVEDĪBAS PROFILAKSE, SAMAZINOT SKOLAS KAVĒJUMUS

Britta Alin Akerman, Anna Dahlberg, Helena Björk

INTERNAL EVALUATION OF THE QUALITY OF A SPECIAL EDUCATION STUDY

PROGRAMME

SPECIĀLĀS IZGLİTİBAS STUDIJU PROGRAMMAS KVALITĀTES PAŠNOVĒRTĒJUMS

Daiva Alifanoviene, Stefanija Alisauskiene, Jonas Ambrukaitis, Albina Kepalaite

ADJUSTMENT OF WISHES AND POSSIBILITIES OF THE DISABLED YOUTH

IN THE EDUCATIONAL PROCESS

JAUNIEŠU AR TRAUCĒJUMIEM VĒLMJU UN IESPĒJU SAKĀRTOŠANA

IZGLĪTİBAS PROCESĀ

Ingrida Baranauskienè 
DIRECTIONS FOR IMPROVEMENT OF VOCATIONAL TRAINING

OF THE DISABLED YOUTH

NOSACĪJUMU PILNVEIDOŠANA JAUNIEŠU AR İPAŠĀM VAJADZĪBĀM

SAGATAVOŠANAI DARBAM

Ingrida Baranauskiené, Reda Baranauskienè

SPECIFICS OF THE TRANSITION PROCESS FROM PRESCHOOL TO ELEMENTARY SCHOOL FOR CHILDREN WITH SPECIAL NEEDS

BĒRNU AR SPECIĀLĀM VAJADZĪBĀM PĀREJA NO PIRMSSKOLAS UZ SĀKUMSKOLU

Dina Bethere

THE TEACHER AS A CULTURE CARRIER - THE ABILITY TO PERSONIFY IDEAS,

FEELINGS, THOUGHTS, ACTIONS, AND VALUES 540

SKOLOTĀJS KĀ KULTŪRAS NESĒJS - SPĒJA PERSONIFICĒT IDEJAS, JŪTAS,

DOMAS, DARBĪBU UN VĒRTİBAS

Rutger Ingelman

ANALYSIS OF PROFESSIONAL COMPETENCE DEVELOPED IN A SPECIAL

EDUCATION STUDY PROGRAM

PROFESIONĀLĀS KOMPETENCES ATTĪSTĪBAS ANALĪZE SPECIĀLĀ IZGLĪTĪBAS

STUDIJU PROGRAMMĀ

Albina Kepalaitè, Stefanija Ališauskienè, Daiva Alifanovienè, Jonas Ambrukaitis

SPECIĀLĀS IZGLĪTĪBAS SKOLOTĀJU SAGATAVOŠANA LATVIJAS UNIVERSITĀTĒ

TRAINING OF TEACHERS OF A SPECIAL EDUCATION SCHOOL

AT THE UNIVERSITY OF LATVIA

Sarmīte Tübele

SPECIĀLĀS IZGLİTĪBAS PROGRAMMU LİMEN̦U DIFERENCIĀCIJA 562

DIFFERENTIATION OF THE LEVELS OF THE PROGRAMMES OF SPECIAL EDUCATION

Rasma Vīgante

7. DEVELOPMENT OF TEACHERS' LEADERSHIP COMPETENCE

575

ACTION RESEARCH IN LITHUANIAN SCHOOLS AS A PRECONDITION FOR LIFE-LONG

LEARNING

DARBĪBAS IZPĒTE LIETUVAS SKOLĀS KĀ MŪŽIZGLĪTĪBAS NOSACĪJUMS

Reda Baranauskienè, Ingrida Baranauskienè

SCHOOL AS A MULTILEVEL LEARNING ORGANIZATION 588

SKOLA KĀ DAUDZLĪMENU MĀCĪŠANĀS ORGANIZĀCIJA

Maija Kokare

TEACHERS' PROFESSIONAL DEVELOPMENT: QUALIFYING FOR QUALITY

SELF-EVALUATION AND REFLECTION ON EDUCATIONAL PRACTICE 597

SKOLOTĀJU PROFESIONĀLĀ ATTĪSTĪBA - KVALIFICĒŠANA PAŠNOVĒRTĒŠANAI

UN REFLEKSIJAI UZ MĀCĪBU PRAKSI

Maja Ljubetić

LEARNING-CENTERED LEADERSHIP 605

MĀCIIŠANĀS VADĪBA

Ivars Muzis

A PROJECT OF LATVIAN VOLLEYBALL FEDERATION "VOLLEYBALL ABC" -

HOW TO DEVELOP VOLLEYBALL IN LATVIAN SCHOOLS?

LATVIJAS VOLEJBOLA FEDERĀCIJAS PROJEKTS "VOLEJBOLA ABC" -

KĀ ATTİSTİT VOLEJBOLU LATVIJAS SKOLĀS?

Tamara Shkolnikova, Herbert Zoglowek 
LĪDERİBAS UN AUTORITĀTES JĒDZIENI SKOLOTĀJA PROFESIONĀLAJĀ

DARBĪBĀ

CONCEPTION OF LEADERSHIP AND AUTHORITY AS A COMPONENT OF TEACHER'S

PROFESSIONAL ACTIVITY

Sandra Smilga

CRITERIA OF LEADERSHIP AND AUTHORITY AS A COMPONENT OF TEACHER'S PROFESSIONAL ACTIVITY

LİDERĪBAS UN AUTORITĀTES KRITĒRIJI SKOLOTĀJA PROFESIONĀLAJĀ DARBĪBĀ

Sandra Smilga, Irēna Žogla

8. FURTHER DEVELOPMENT OF TEACHER EDUCATORS' PEDAGOGICAL COMPETENCE

THE TEACHER TRAINING RESOURCE BANK (TTRB): A FREE EVIDENCE INFORMED RESOURCE FOR THE PROFESSION BY THE PROFESSION 651 SKOLOTĀJU IZGLİTĪBAS RESURSU BĀZE

Mike Blamires, Cathy Lawrence

AUDZĒKN̦U EKOLOĢISKĀS ATTIEKSMES ATTĪSTĪBA MĀCĪBU PROCESĀ BŪVNIECİBAS SPECIALITĀTĒ PROFESIONĀLĀS IZGLĪTĪBAS SKOLĀ 663 DEVELOPMENT OF STUDENTS' ECOLOGICAL ATTITUDE IN THE STUDIES OF BUILDING IN A VOCATIONAL SCHOOL Andris Bērzingš

TEACHER EDUCATION IN THE CONTEXT OF THE BOLOGNA PROCESS 673 SKOLOTĀJU IZGLİTĪBA BOLON̦AS PROCESA KONTEKSTĀ Dainuvite Bluma

MANAGING MENTORSHIP THROUGH A POSITIVE RELATIONSHIP 681 POZITĪVAS SAVSTARPĒJĀS ATTIECIIBAS MENTORU DARBA PĀRVALDĒ Linutè Kraujutaitytè, Alona Rauckienè

DEVELOPMENT OF STUDENTS' ESP COMPETENCE AND EDUCATORS' PROFESSIONAL ACTIVITY IN TERTIARY LEVEL TOURISM STUDIES 689 STUDENTU PROFESIONĀLĀS ANGLUU VALODAS KOMPETENCES UN DOCĒTĀJU PROFESIONĀLĀS DARBIIBAS ATTİSTĪBA TŪRISMA STUDIJĀS

Ineta Lūka

THE ROLE OF AN EDUCATOR IN FURTHER EDUCATION OF ADULTS 698 DOCĒTĀJA LOMA PIEAUGUŠO TĀLĀKIZGLĪTĪBĀ

Oksana Shalajeva

Aivars Lasmanis

PROFESSIONAL DEVELOPMENT OF EDUCATORS AIMED AT RESEARCH AND CHANGE OF THEIR OWN EDUCATIONAL PRACTICE 707

DOCĒTĀJU PROFESIONĀLĀ ATTĪSTĪBA AR MĒRĶI APGŪT PĒTNIECISKO PRASMI UN MAINĪT SAVU PEDAGOĢISKO PRAKSI

Edita Slunjski

TEACHER EDUCATOR, GO EDUCATE THYSELF: WHO TEACHES THE TEACHERS OF TEACHERS?ESTABLISHING A MODEL OF PROFESSIONAL FORMATION FOR TEACHER EDUCATORS IN FURTHER EDUCATION COLLEGES. 714 DOCĒTĀJ, EJ UN MĀCIES: KAS MĀCA SKOLOTĀJU SKOLOTĀJUS?

Christopher Spencer 
MODEL OF STRUCTURE OF PERSONAL INNOVATIVENESS IN EDUCATION AND INNOVATIONAL ANXIETY: PILOT RESEARCH RESULTS 723

PERSONĪBAS INOVĀCIJU PIEN̦EMŠANAS STRUKTURĀLAIS MODELIS IZGLĪTĪBĀ

UN PERSONĪBAS INOVĀCIJU TRAUKSME:PILOTPĒTİJUMA REZULTĀTI

Svetlana Baigozina, Aivars Lasmanis, Eduard Saveliev, Tälivaldis Mežis, Irina Filipova

PATSTĀVĪGAS STUDĒTPRASMES UN KRITISKĀ DOMĀŠANA KĀ GALVENIE NOSACĪJUMI, UZSĀKOT STUDIJAS 734

INDEPENDENT STUDYING SKILLS AND CRITICAL THINKING AS THE MAIN

CONDITIONS FOR BEGINNING STUDIES

Irina Kazuša

DEVELOPMENT OF INDIVIDUAL AESTHETIC CULTURE AS A PHILOSOPHICAL

AND PEDAGOGICAL PROBLEM 740

ESTĒTISKĀS KULTŪRAS ATTĪSTĪBA KĀ FILOZOFISKA UN PEDAGOGISKA

PROBLĒMA

Vladimirs Kincāns

AN APPROACH TO THE INTEGRATION OF QUALITATIVE AND QUANTITATIVE

RESEARCH METHODS IN RESEARCH OF PEDAGOGY 746

INTEGRĒTĀ PIEEJA KVALITATİVAJĀM UN KVANTITATĪVAJĀM METODĒM

PEDAGOĢIJAS PĒTĪJUMOS

Aivars Lasmanis

TEACHER AS A GUIDE IN VEDIC EDUCATIONAL PHILOSOPHY

SKOLOTĀJS - CELVEDIS VĒDISKĀS IZGLĪTĪBAS FILOZOFIJĀ

Gunta Ořeniece

PRE-SERVICE TEACHERS' COMPETENCE IN RESEARCH AND PRECONDITIONS

FOR OBTAINING QUALIFICATION 764

TOPOŠO SKOLOTĀJU ZINĀTNISKO PĒTİJUMU KOMPETENCE UN NOSACĪJUMI

TO ATTİ́STİBAI

Palmira Pečiuliauskienè, Marija Barkauskaitè

IMPLICATIONS OF TOTALITARIAN VALUES IN THE POST-SOVIET EDUCATIONAL

SPACE:THE THEORETICAL AND METHODOLOGICAL RESEARCH BASIS 773

TOTALITĀRISMA VĒRTĪBU IMPLIKĀCIJAS POSTPADOMJU IZGLĪTĪBAS TELPĀ

Zanda Rubene, Laima Geikina, Artis Svece, Inga Vanaga, Beatrise Garjāne,

Oksana Kuzmenko, Aiva Līduma

10. HISTORY OF TEACHER EDUCATION (INVITED SESSION

OF BALTIC ASSOCIATION OF EDUCATIONAL HISTORIANS)

782

LITERATŪRAS MĀCĪBU METODIKAS PAMATIDEJAS 20. GADSIMTA 70.-80. GADOS 784 BASIC IDEAS OF METHODS OF TEACHING LITERATURE IN THE 70-80

OF THE $20^{\text {TH }}$ CENTURY

Dagmāra Ausekle, Elita Stikute

СТАНОВЛЕНИЕ И РАЗВИТИЕ ПЕДАГОГИКИ КАК УЧЕБНОЙ ДИСЦИПЛИНЫ

В СОВЕТСКОМ ОБРАЗОВАНИИ:ИСТОРИОГРАФИЧЕСКИЙ АНАЛИЗ 789

THE FORMATION AND DEVELOPMENT OF PEDAGOGY AS A TEACHING SUBJECT

IN SOVIET EDUCATION: A HISTORIGRAPHIC ANALYSIS

PEDAGOGIJUAS KĀ STUDIJU DISCIPLĪNAS RAŠANĀS UN ATTĪSTĪBA PADOMJU LAIKA

IZGLĪTĪBĀ: HISTORIGRĀFISKA ANALĪZE

Татьяна Курилова 
CHILDREN WITH SPECIAL AND EXCEPTIONAL NEEDS - A SUBJECT IN THE

TEACHER TRAINING CURRICULUM (LATVIA, THE LATE 19TH CENTURY - 2004)

BĒRNI AR SPECIĀLĀM UN İPAŠĀM VAJADZĪBĀM - MĀCĪBU PRIEKŠMETS SKOLOTĀJU

IZGLİTİBAS PROGRAMMĀS (LATVIJĀ 19. GS. BEIGĀS - 2004)

Iveta Ķ Kestere, Dita Nīmante

SCHOLACTISICM IN MEDIEVAL SCHOOLS

SHOLASTICISMS VIDUSLAIKU SKOLĀS

Dalia Marija Stančienè, Juozas Žilionis

THE ACTIVITIES OF THE PRIVATE RUSSIAN TECHNICAL SCHOOL OF ENGINEER NIKOLAJ OKOLO-KULAK

INŽENIERA NIKOLAJA OKOLO-KULAKA PRIVĀTĀ KRIEVU TEHNIKUMA DARBĪBA

Alīda Zigmunde

11. INVITED SESSION. COMPETENCE OF MUSIC TEACHER

IN THE $21^{\mathrm{ST}}$ CENTURY

DEVELOPMENT OF MUSIC TEACHER'S REFLECTIVE ACTIVITY:

THEORETICAL ASPECT 831

MŪZIKAS SKOLOTĀJU REFLEKSIJAS ATTĪSTĪBAS TEORĒTISKIE ASPEKTI

Jelena Davidova, Tatyana Minakova

MŪZIKAS SKOLOTĀJA EMOCIONĀLĀS KOMPETENCES TEORĒTISKIE ASPEKTI

UN STRUKTŪRA

MUSIC TEACHER'S EMOTIONAL COMPETENCE AND ITS STRUCTURE

Laimrota Kriumane, Māra Marnauza

KLAVIERSPĒLES APGUVES AKSIOLOĢISKĀS PIEEJAS TEORĒTISKAIS PAMATOJUMS

SOME THEORETICAL PRINCIPLES WITHIN THE AXIOLOGICAL APPROACH TOWARDS

TEACHING PLAYING THE PIANO

Larisa Maļkova, Tamāra Bogdanova

MŪZIKAS UZTVERES UN MUZIKĀLĀS GAUMES MIJIEDARBĪBA

861

CORRELATION OF MUSIC PERCEPTION AND MUSICAL TASTE

Marina Marčenoka

MUZIKĀLI IZGLİTOJOŠS PROCESS: VĪZIJA UN REALITĀTE 868

THE PROCESS OF MUSIC EDUCATION: VISIONS AND REALITY

Marina Marčenoka, Anna Tatarinceva

MŪZIKAS SKOLOTĀJU PROFESIONĀLĀS PILNVEIDES IESPĒJAS

EIROPAS KOMISIJAS AUGSTĀKĀS IZGLĪTĪBAS STUDENTU UN DOCĒTĀJU

MOBILITĀTES PROGRAMMĀ ERASMUS 876

OPPORTUNITIES OF MUSIC TEACHERS' PROFESSIONAL DEVELOPMENT

IN THE HIGHER EDUCATION STUDENT AND TEACHER MOBILITY PROGRAMME

OF THE EUROPEAN UNION - ERASMUS

Maruta Sïle, Ilze Freimane

DŽEZA IMPROVIZĀCIJAS APGUVE: VĒSTURE, TEORIJA, PIEREDZE 886

JAZZ IMPROVISATION MASTERING: HISTORY, THEORY, EXPERIENCE

Jurijs Spigins

FERENCA LISTA PEDAGOĢIJAS UZSKATI SAISTĪBĀ AR DIDAKTIKAS KATEGORIJĀM 894 THE PEDAGOGICAL VIEWS OF FERENZ LIST IN INERRELATION WITH DIDACTIC CATEGORIES

Jeḷena Treijere, Tamāra Bogdanova 



\section{PLENARY REPORTS}

May 2, 15.00

Mazā aula

Raiṇa bulvāris 19

Riga, Latvia 


\title{
NENOZĪMĪBAS ĪPATNĪBAS. PEDAGOGIJAS VĒSTURE SKOLOTĀJU IZGLĪTĪBĀ QUALITIES OF IRRELEVANCE. HISTORY OF EDUCATION IN THE TRAINING OF TEACHERS
}

\author{
Marc Depaepe \\ Katholieke Universiteit Leuven
}

\begin{abstract}
Anotācija
Šajā rakstā aplūkota pedagog̣ijas vēstures kā zinātnes disciplīnas un kā studiju kursa attīstības ciešā saikne. Rakstā iztirzāti jautājumi par to, kāda pedagoǵijas vēsture tika mācīta, un vai pedagogi uzskata, ka mūsdienās pedagoǵijas vēsture var būt atraktīva. Autors noliedz centienus pedagogiijas vēsturi padarīt par līdzekli praktisku problēmu risināšanai, nākotnes prognozēšanai, tradicionālo vērtību leǵitimizēšanai. Tikpat nepieņemama ir arī pedagoǵijas vēstures politizēšana un ideoloǵizēšana gan no baznīcas, gan valsts puses. Problēmas pedagoǵijas vēsturē kā zinātnes disciplīnā atspoguḷojas arī pedagoǵijas vēstures studiju kursā. Rakstā analizēti šī studiju kursa zemās popularitātes cēloṇi līdz II pasaules karam, kad paradigmas maiņa un 20. gs. 60. gadu revizionisms (L. Kremins, B. Beilins) pavēra plašāku vēstures sociokulturālo perspektīvu. 80. gados raksturīga “jaunā" kultūras vēsture, bet postmodernisma laikmetā - vēstures rakstī̌sanas un pārrakstīšanas "bezgalīgais uzdevums" ar pagātnes stāstu dekonstruēšanu un demitolog̣izēěanu. Mūsdienās, kad izglîtīiba ir kḷuvusi par biznesu, vēsturiskā pieeja aizšķērso ceļu utilitārismam, tūlītēja praktiskā izmantojuma "teroram".
\end{abstract}

Atslēgvārdi: pedagogiijas vēsture kā zinātnes disciplīna, pedagoğijas vēsture kā studiju kurss, skolotāju sagatavošanas programmas.

Gandrīz pirms desmit gadiem bijušais $I S C H E^{1}$ prezidents Jurgens Herbsts vēlējās "portretēt" pedagogijas vēsturi ${ }^{2}$ Ziemel̦amerikā un Eiropā 20. gadsimta beigās. Vin̦š secināja, ka pedagogijas vēsturniekiem vajadzētu "no jauna [pasvītrojums mans - M. D.] pārdomāt savu klātbūtni profesionālās izglītības programmās"’. "No jauna" šajā kontekstā nozīmēe, ka reiz ir pastāvējusi patiesi nozīmīga, būtiska pedagoǵijas vēsture, kas patiešām bija integrēta skolotāju sagatavošanas programmās. Tas liek jautāt: kāda gan ir bijusi pedagoǵijas vēsture pagātnē, un vai pedagogijas vēsturei joprojām piemīt potenciāls būt atraktīvai pedagogu auditorijā? Šie jautājumi ${ }^{4}$ man kā pedagoǵijas vēsturniekam šķiet laba starta pozīcija, lai atklātu starptautisku konferenci par skolotāju izglītības kvalitātes paaugstināšanu 21. gadsimtā ${ }^{5}$.

Marija Madlēna Kompēra ${ }^{6}$ un es ${ }^{7}$, tāpat kā citi, esam mēginājušsi skaidrot, ka kopš 19. gadsimta pēdējā ceturkšņa pedagoǵijas vēstures panākumi skolotāju izglītībā (gan ASV, gan Eiropā) ir bijuši atkarīgi no lielo meistaru (tādu kā Montēņs, Komenskis, Fenlons, Ruso, Pestalocijs un Frēbels) teoriju nozīmīguma un varbūt vēl lielākā mērā no cerībām iedvest topošajos skolotājos "pedagoǵiski pareizu" attieksmi. Francijas pedagoǵijas vēstures standartu radītājs Gabriels Kompērs (1843-1913) 1884. gadā rakstīja, ka dažādas lielo domātāju pedagoǵiskās teorijas ir labs palīgs tikumiskai pārliecināšanai. Grūti iztēloties, ka Herbsts gribētu atjaunot šādu vecmodīgu pedagoğijas vēstures moralizēšanu. Tāpat kā citi vadošie nozares speciālisti, kas piedalījās Spensera fonda ${ }^{8}$ sponsorētajā konferencē "Jauni virzieni pedagoǵijas vēsturē", viņš uzskata, ka Amerikas pedagoǵijas vēstures zelta laikmets ir nevis 19. gadsimts, bet gan 20. gadsimta 60. un 70. gadu kultūras revizionisma ēra, kad pētījumus ASV lielā mērā noteica Beilina, Kremina un citu "metodoloǵiski organizētā historiogrāfija" pieņemt ${ }^{10}$, ka paradigmu maiņu rosināja kultūras revizionisms: ideju vēsture tika nomainīta ar pedagogijias sociālās vēstures postulātiem. 
Rūpīgāka evolūcijas izpēte tomēr atklāj daudzveidību, kas izmantojama kā pretlīdzeklis monolītajai un nevēsturiskajai pedagoğijas "vēstures vēstures" konceptualizācijai, kā to nosaucis Sols Koens ${ }^{11}$. Heincs Elmārs Tenorts un citi vācu zinātnieki jau 20. gs. 70. gadu vidū ${ }^{12}$ novēroja, ka "jaunā sociālā pedagoǵijas vēstures paradigma" var lepoties tikai ar dal̦ēju vienprātību attiecībā uz metodoloǵisko problēmu šaurākā nozīmē: vispār tiek atzīti sociālvēsturiskie pētniecības instrumenti un tehnikas, ieskaitot kvantitatīvās metodes. Tomēr tas nenovērš būtiskas atšķirības metodologiisko problēmu plašākā vērtējumā, proti, jautājumā par saikni starp teoriju un vēsturi ne tikai pedagogijāâ, bet sociālajās zinātnēs kopumā. Kā esmu iepriekš norādījisis ${ }^{13}$, Rietumvācijā valdīja visai liela nevienprātība par zinātnes teorētiskajām nostādnēm. Pedagogijas vēsturniekam, protams, ir svarīgi, vai viņa pētījums ir ierobežots līdz pirmszinātniskam "hipotēžu rezervuāram", kā sacījis empīrisko pētījumu krusttēvs Volfgangs Brezinka, vai arī viņa pêtījums ir izglìtības teorijas veidošanās centrā līdzịgi kā Ulriha Hermana vēsturiskās socializācijas pētījums vai ideologiski kritiskie un neomarksistiskie pētījumi Rietumvācijā un Austrumvācijāa $\bar{a}^{14}$.

Šìs atšķirības teorētiskajās koncepcijās radīja arī praktiskas sekas starptautiskajā pedagoǵijas vēstures zinātnieku vidē. "Jaunā” pedagoǵijas sociālā vēsture, pateicoties Braienam Simonam, Morisam de Vrēdem un Jurgenam Herbstam, iedvesmoja $I S C H E^{15}$ nodibināšanu un attīstību. Taču tā nekavēja vecmodīgu un, manuprāt, pat diletantisku centienu uzplaukumu šajā organizācijā attiecībā uz pedagogíjas vēstures nozīmīgumu praktisku problēmu risināšanā ${ }^{16}$. Viena no grāmatas, kas tika prezentēta kā $I S C H E$ pastāvīgās darba grupas "Pedagoǵijas vēsture kā pētniecības nozare un kā mācību priekšmets" sanāksmju rezultāts, redaktorēm vienkārši atkārtoja vecmodīgās 19. gadsimta "vēsturiskās pedagogijijas" pieņēmumus: "Ar piemēriem no pagātnes mantojuma [kā Komenskis, Pestalocijs, Djūijs, Makarenko un Suhomḷinskis] mēs varam veidot nākotnes skolotāju domāšanas veidu, viņu pedagoǵiskos uzskatus un attieksmi pret darbu.. Dažādu laikmetu pozitīvie sasniegumi kalpo kā pedagoǵijas vēstures prognozējošā funkcija: tie parāda vienas vai citas koncepcijas dzīvotspēju, praktiskos risinājumus un iespējas tos lietot, ņemot vērā jauna laikmeta prasības.. Pedagoǵijas vēsture ir zinātne par teorētiskās un praktiskās attīstības likumībām (likumiem).. Pedagogijas vēsture arī turpmāk dos savu ieguldījumu jaunu uzdevumu risināšanā, kurus izvirza mūsu laiks un diktē modernizācijas prasības, kā arī 21. gadsimta izglîtīibas reformas" ${ }^{\prime 17}$.

Nevēloties tikt apsūdzēts metodologiskā imperiālismā, es 1992. gadā, būdams ISCHE prezidents, uzskatīju par savu pienākumu brīdināt no utilitāra pagātnes pedagoǵiskā mantojuma traktējuma ${ }^{18}$. Uzskatu, ka izteikta tiekšanās pēc ideologiska, teorētiska vai praktiska labuma neizbēgami izraisīs mistifikāciju ${ }^{19}$ un pat vēstures prostituēšanu līdz hagiogrāfijai ${ }^{20}$, pedagogisko varoṇu kultu un vēstures obligātu piesaisti mūsdienām. Par šādu viedokḷ u eksistenci es pārliecinājos, pieņemot ielūgumu 1994. gada oktobrī piedalīties Ķīnas un Šveices "Pestalocija projektā", kā arī 1995. gada septembrī, kad tiku uzaicināts novērtēt pedgoǵijas vēstures pētījumus un studiju kursa docēšanu Dienvidāfrikas Gautangas (bijušās Transvālas) provinces universitātēs. Abos gadījumos manas kritiskās piezīmes ${ }^{21}$ sadūrās ar vienkāršotiem spriedumiem par pagātnes mācību, slēpjot ar izglītības reformām saistītās specifiskās pedagoǵiskās un politiskās intereses ${ }^{22}$.

Nacionālā līmenī saskaņotie centieni popularizēt Pestalocija idejas Ķīnā mēdz sakrist ar liela mēroga analfabētisma likvidēšanas kampaņām, kurās centrālo vietu ieņem roku darba un formālās izglìtîbas integrācija ${ }^{23}$. Pestalociju Ķīnā padara pievilcīgu ne tik daudz viṇa "pamatīgais vēsturiskais nozīmīgums", bet gan vina "izcilais tūlìtējais nozīmīgums", kas atspoguḷojas šādos secinājumos: "mūsu laikmeta cilvēku uzmanību saista Pestalocija pedagoǵisko ideju kvintesence, lai vadītu un veicinātu izglīīibas reformu"; "aktīvās mācīšanas kodols mūsdienās (..) joprojām ir Pestalocija pamatidejas"; "ar izglīīibai veltīto dzīvi un nelokāmo gribasspēku Pestalocijs vienmēr būs lielisks piemērs visas pasaules pedagogiem"; "Pestalocija idejas par [darba un tehnisko] izglītību joprojām ir nozīmīgas mūsdienu pedagoǵiskajā praksē”; 
“ja kādam cilvēkam piemīt Pestalocija universālā mīlestība un gatavība glābt pasauli, viṇu piepildīs "svēta aizrautība" un viņš uz mūžu kḷūs veiksmīgs" utt. ${ }^{24}$.

Ironiski, ka līdzīgi mēginājumi atrast pagātnes mantojuma derīgu izmantojumu sastopami dažās konservatīvās (balto) aprindās Dienvidāfrikā, kur "vēsturiskā pedagoǵija" joprojām tiek izmantota, lai leǵitimizētu tradicionālās vērtības (neoficiāli pat ar ISCHE karogu!). Pamatojoties uz tā saucamo paedagogica perennis - fenomenoloǵisku konstrukciju par pedagogiijas būtību, kas atvasināta no vēstures -, var sadzirdēt aicinājumus pēc "kultūrā balstītas" (vienā kultūrā) izglītības dažādām etniskām un reliǵiskām grupām vienā valstī: "Izglītība un kultūra gadsimtu gaitā vienmēr ir bijušas savstarpēji saistītas. Kultūra, reliǵija, vietējā valoda un vēsturiskums vienmēr ir bijušas autentiskas izglītības dalas. Atcerieties to, kad vērtējat skolu integrāciju Dienvidāfrikā.. Dažādu kultūru bērnu sablīvēšana vienā klasē noliedz paedagogica perennis. Kura valoda, vēsture, reliǵija, normas, vērtības un kurš kultūras mantojums tiks mācīts? Nedrīkst neievērot izglīî̄bas būtību, autentiski izglītojot bērnus atbilstošai pieaugušo dzīvei. To mēs esam parādā saviem bērniem. Multikulturālās skolās daudziem bērniem tiks atņemta viņu dzimtā valoda, kultūras mantojums un reliǵija. Pārspīlēti tiek uzsvērta zināšanu, prasmju un sagatavošanās nākotnes darbam nozīme. Pedagoǵiski [sic!] pamatotas ir kultūrā balstītas skolas" 25 .

Lai gan politiskās un ideoloǵiskās varas ietekme uz šādiem vēstures pētnieku (arī pedagoǵijas vēsturnieku) spriedumiem vēl jāpierāda, studējot attiecīgo sociālo un kultūrvēsturisko kontekstu, tas mani vedina uz domām par to, kā katoḷi Flandrijā sīki izstrādāja pedagogijas vēstures mācību priekšmetu. Pēc Pirmā pasaules kara divi priesteri pedagogi de Hovrs un Dekēns centās nostiprināt izglītības katoliskos pamatus ar laikraksta Vlaamsch Opvoedkundig Tijdschrift ${ }^{26}$ palīdzību. Viṇu sludinātie mērķi bija "konservatīva revolūcija", "atdzimšana un kristīšana mūžīgajā atjaunojošajā katoḷu izglītības filosofijâ". De Hovrs uzskatīja katoḷu dzīves filosofiju par visu modernās dzīves teoriju "stūrakmeni, prototipu, Platona ideju, īstas pedagoǵiskās domāšanas būtību, paedagogia perennis, īstas pedagoǵiskās tradīcijas pamatu, pedagoǵiskās gudrības dzimto valodu, pedagogiskās patiesības vēstnesi", pēc kuras būtu jāvērtē visi modernās izglītības teorijas "elki" vai "nepareizie avoti”. Šì kaujinieciskā nostāja nozīmēja, ka ne historiogrāfija, ne pedagoǵijas teorija nevar būt neitrālas. De Hovra vārdiem runājot, "teorija, kas izriet no vēsturisko datu modernās izpratnes, ir parādījusi, ka cilvēka, darba vai notikuma izpratnes pamatā ir personiskās simpātijas". Tādējādi tiek norādīts, ka uz pagātni jāskatās ar katoḷa acīm, kurās lielo pedagoǵijas varoṇu apbrīnošana bija atkarīga no to devuma katoliskās izglītības praksei. Tādēl inovatorus (šajā gadījumā - reformpedagogus, kuri vēlējās sākt ar bērnu), piemēram, Elēnu Keju, Dekēns un de Hovrs dēvēja par lielajiem bērniem, kuri uzradušies bērna gadsimtā, "lai liktu savu izcilo bērnišķību mūžseno vērtību vietā"...

Fakts, ka katoliskajā Flandrijā ilgu laiku turpināja izskanēt šādi pien̦ēmumi, neizraisa debates. Daudz ievērojamāka, iespējams, ir šo pieņēmumu zinātniski teorētiskā analoǵija ar pedagoǵijas vēstures un pedagoǵijas teorijas marksistiski l̦eņiniskajiem principiem bijušajā Austrumu blokā, konkrētāk - VDR, kur daudz uzmanības tika veltīts teorijas metodologiskajiem pamatiem ${ }^{27}$ (protams, pretstatot tos Rietumu "imperiālistiskajai" (lasi: kapitālistiskajai) pedagoǵijas teorijai Vācijā). Arī Austrumu blokā "logiiskā" (teorētiskā) un "vēsturiskā" (dialektisks) apvienojums veidoja (vēsturiskās) pedagoǵijas teorijas pamatu. Marksistiski l̦eņinistiskās epistemoloǵijas ietvaros pagātne tika vērtēta kā neizbēgams un nepieciešamsattīstības process, kas ved uz sociālistisko sabiedrību. Cilvēku sabiedrības vēsture tika aplūkota kā šķiru konfliktu virkne. Dažādajās šksiru cīņas epizodēs kā konflikta kulminācijas punkti iezīmējas revolūcijas. Kopš šķiru sabiedrība pēc lielās revolūcijas bija transformējusies par sociālistisku (domāts komunistisku), tā atbrīvojās no savas pavēloši aklās determinisma dabas. Šajā sabiedrības formā cilvēki apguva zināšanas par spēkiem, kas determinē sabiedrību. Tādējādi viņi kḷuva par vēstures "kungiem" un varēja izmantot šīs zināšanas, lai īstenotu sociālistu vēstìjumu par "pestī̌sanu". Šis skatījums marksisma l̦eņinisma pedagog̣ijas teorijā ḷāva lietot mutatis 
mutandi $s^{28}$. Progresīva nākotnes plānošana un konstruēšana nav iespējama bez sistemātiskas pagātnes pētīšanas. Tāpat kā pagātne, tagadne un nākotne, arī teorija un prakse marksismā l̦eņinismā bija vienotas, viena no otras (“dialektiski”) neatdalāmas.

No šiem teorētiski metodoloǵiskajiem pamatiem izrietēja daudzas funkcionālas sekas gan izglītībā, gan pedagogijijas vēsturē, kas tika uztvertas ne tikai kā izglīitības teorijas centrs, bet arī kā būtiska vispārējās kultūras vēstures sastāvdaļa. Vispirms, īpaši skolotāju auditorijā, bija jāatklāj pagātnes "pedagoǵiskais mantojums", jo iepriekšējo pedagogu "progresīvās" pieredzes pārzināšana bija lıoti noderīga vēsturiskās, plašākā nozīmē - sociālistiskās, apziņas veidošanā. Vēl vairāk, asociēšanās ar "sociālistisko" mantojumu labi iederējās cīṇā pret "imperiālistisko" ārzemju ietekmi. Treškārt, tika cerēts, ka problēmorientēts skats uz pagātni nodrošinās palīdzību mūsdienu problēmu risināšanā un būs palīgs nākotnes pareǵojumiem.

Šāda "dīvaina pagātnes izmantošana" 29 neattiecās tikai uz Austrumvāciju, bet uz visu Padomju Savienības ietekmes zonu ${ }^{30}$, ieskaitot Latviju ${ }^{31}$, un tas man atgādina kultūrrevizionismu ASV. Taču pedagogijas vēstures funkcionālā vērtība ir labāk izprotama, pētot šī mācību priekšmeta ilgo vēsturi. Lai gan šķiet, ka pedagogijas vēsture no 19. gadsimta beigām ir neatnemama ASV u. c. valstu skolotāju sagatavošanas programmu sastāvdaļa, pēc Pirmā pasaules kara pret to pieauga neuzticība: šķita, ka šai programmas daḷai vairs nav pragmatiska attaisnojuma ${ }^{32}$. 20. gs. 20. un 30. gados tas noveda pie plašām debatēm par pedagoǵijas vēstures funkcionālo vērtību. Kā liecināja 1917. gada aptauja, tikai 12,7\% skolotāju bija pārliecināti, ka šis studiju kurss viņiem ir bijis noderīgs ${ }^{33}$. Akadēmisko pedagoǵijas vēsturnieku atbilde galvenokārt attiecās uz priekšmeta saturu. Viņi izmantoja valsts izglītības nozīmi, šajā gadījumā priekšrocības, kas bija saistītas ar Amerikas sabiedrības struktūru. Skola tika aplūkota kā demokrātijas (lasi: meritokrātijas) dzinējspēks, kā to dēvēja Elvuds P. Kiberlijs ${ }^{34}$. Viṇš noteica toni, konstruējot lineāri progresīvu pedagoğijas vēstures skatījumu ${ }^{35}$. Šis triumfālais stāsts iekl̦āvās vispārējā (vigu36) interpretācijā par mērķorientētu progresu (Rietumu) civilizācijā, no kuras netiek gaidīts nekas cits kā tikai sasniegumi (aizvien vairāk un aizvien labāk).

Šie funkcionālie maldi, kā Frederiks Lilgs 1947. gadā nodēvēja pedagoǵijas vēstures izpratni Amerikāa ${ }^{37}$ nebūt nebija beigušies. "Panākumu stāsts" Kiberlija stilā turpmāk akcentēja profesionālo diskursu un pedagogu ètosu. Turklāt sociālrekonstruktīvisti 30. gados aizvien skaļāk pieprasīja problēmorientētu pieeju sociālajās zinātnēs. Tikai tā "jaunā" sabiedrība varot spēt risināt mūsdienu problēmas. Tādēl pedagoğijas vēsture riskēja tikt reducēta uz daļu no sociālo pamatu kursa un koncentrēta uz aktuāliem notikumiem.

Tikai pēc Otrā pasaules kara pavērās plašāks ceľ̦s sociokulturālai perspektīvai, kurā pedagoǵijas vēsture vairs netika uzlūkota kā attīstība "formālajā pedagoǵijā, bet gan kā pilnvērtīgs process, ar kuru kultūra tiek nodota no paaudzes paaudzē"،38. Šo paradigmu mainu veicināja tā dēvētais 60. gadu revizionisms, ko zinātniski organizatoriskā līmenī akcentēja "Pedagoǵijas vēstures biedrības" ${ }^{99}$ nodibināšana 1960. gadā un žurnāla "Pedagoǵijas Vēsture. Ceturkšña Izdevums" laišana klajā 1961. gadā. Starp citu, šīs pedagoǵijas vēstures (jaun-?) attīstības dēḷ Edgars B. Veslijs mainīja savu 36 gadus ilgušo sēru dziesmu "Vai, nabaga pedagogiijas vēsture!"41 pret gavilējošo "Sveika, plaukstošā pedagoǵijas vēsture!"’2

Praksē revizionisms, kurā galveno lomu tēlotāji bija Bernards Beilins un Lerijs Kremins, nozīmēja plašāku skatu uz audzināšanu un izglītību. Revizionisti, būdami profesionāli vēsturnieki, uzbruka tādu pedagogu kā Kimberlijs aprobežotajām tēzēm par valsts izglītības "uzvaru" amerikāņu demokrātijā. Par to revizionisti samaksāja ar apsūdzību tādos metodoloǵiskos grēkos kā prezentisms ${ }^{43}$ un evaņgéelisms ${ }^{44}$. "Pagātne bija vienkārši tagadne, kas uzrakstīta maza" "'B5et vislielākā zelta laikmeta ironija bija" - kā Donāto un Lazersons raksta savā diskusiju pārskatā par Amerikas pedagogijas vēstures virzieniem - "ka radikālie revizionisti pievērsa sev uzman̄̄bu, nodarbojoties ar to, ko iepriekšējās pedagoǵijas vēsturnieku paaudzes bija izdarījušas: viṇi pieprasīja tūlītēju saikni ar tagadni’"46. Tik tiešām, radikālie revizionisti, viṇu vidū Maikls Kats kā pionieris, apgrieza veco Kiberlija tēzi ar kājām gaisā. 
Skola Savienotajās Valstīs nebūt nedarbojās kā demokratizācijas dzinulis, bet gan balstījās uz rasismu, šķiru nevienlīdzību un nevienādām iespējām. Kā terapeitiskā izmeklējumā ar ideālizētu pagātni pedagogíjas vēsturei vajadzēja norādīt turpmākās izglītības attīstîbas iespējas un prioritātes, izmantojot kritisku, visumā arī neomarksistiski iekrāsotu radikālā revizionisma perspektīvu. Tādēl tādi postrevizionisti kā Raviča apsūdzēja radikālus par kārtējo "durvju pavēršanu” propagandai un vēstures politizēšanai ar viņu diezgan kreisajām interpretācijām. Radikāliem nevajadzētu aizmirst, ka vinu pētījumus iekrāsoja viņu pieņemumi par tagadni, pat ja viṇi aizstāvēja pedagogijas vēsturi, kurai ir "viņas pašas tiesības un viņas pašas temini” ${ }^{247}$ - tā bez Ravičas novērojuši arī citi zinātnieki ${ }^{48}$.

Tagad revizionisms varbūt ir miris, kā Herbsts atzīmēja jau 80. gados ${ }^{49}$, bet tas automātiski nenozīmē, ka pedagoǵijas vēstures mācībstundu meklējumi ir beigušies. Tieši pretēji. Raviča un citi nepārtrauc "mācīties no pagātnes" ${ }^{50}$. Bet viṇu stāsti ir daudz smalkāki, aizplīvurotāki un varbūt pat bīstamāki nekā iepriekš minētie utilitārisma piemēri ${ }^{51}$.

20. gs. 80. gados ASV un citur parādījās cits "jaunās" pedagoǵijas vēstures piemērs - tā dēvētā jaunā pedagogijijas kulturālā vēsture ${ }^{52}$, kas būtībā varbūt nemaz nebija tik "jauna", jo "vecā" jaunā pedagoǵijas vēsture Vācijā, lietojot Jarauša terminu", aplūkoja gan izglîtības sociālās, gan kultūras dimensijas kā bagātas intelektuālās dzīves izpausmes. Šis pats bieži uzpūsto "paradigmu maiṇu” raksturojums, manuprāt, attiecas uz Amerikas attīstību. Tiešām, tādi vēsturnieki kā R. Frīmans Buts varbūt ticēja, tāpat kā Kiberlijs, Amerikas valsts labdarībai izglîtības sfērā. Viṇi arī iezīmēja, vismaz embrionāli, izglìtības sociokultūrālās analīzes ceḷu jau 40.-50. gados. Buts, piemēram, centās atrast līdzsvaru starp jēgas piešķiršanu vēsturei no tagadnes viedokḷa un pagātnes integritātes atbalstīšanu ${ }^{54}$.

Lai kā arī nebūtu, š̄ "jaunā” pedagoǵijas "kulturālā” vēsture - kurā citu vidū savu ieguldījumu devis arī Sols Koens ${ }^{55}$, lai gan viņa "lingvistiskais pavērsiens" pēdējā laikā tiek apstrīdēts no metodologiskā viedokḷ $a^{56}$ - skaidri pierāda, ka prezentisms ir vairāk vēsturisko pētījumu nosacījums nekā abstrakts metodoloǵisks grēks. Vēstures rakstīšana un pārrakstīšana galu galā pieder tagadnei. Šajā ziņā postmodernisms nespiež mūs darīt neko jaunu, "bet liek to darīt labi un izskatīties darām to labi", atzīst Rojs Lavs ${ }^{57}$. Lai kā mēs nosauktu šîs aktivitātes par "postmodernām" vai "augsti modernām" - tām vienmēr vajadzēs "hermeneitiku", kas Gadamera izpratnē "balstās uz vēsturiskumu un pieredzes lingvistiskumu, meklē jēgas identifikāciju un atmiņu sajūtu, ko stāstītājs kā vidutājs izstrādā kā tekstu, kritiski atjaunojot un rekonstruējot stāsta "baltos plankumus", lai sniegtu analīzei runas un domu skaidrību atbilstoši diskursa kopumam un kontekstam" ${ }^{58}$. Mēs kā cilvēciskas radības, pēc Fuko domām, esam "nolādēti”" rakstīt un pārrakstīt vēsturi no tagadnes viedokḷa. Tas nenozīmē leǵitimizēt sistemātisko pagātnes izkroplošanu saskaņā ar fiksētu ideoloǵisku pozīciju. Tas nozīmē, ka mums kā profesionāliem vēsturniekiem ir jāizpēta, kā mēs paši racionalizējam, loǵiski pamatojam un maskējam savas pētījumu stratēǵijas, pētījuma jautājumus un interpretatīvās tēmas, tāpat kā mums vajag atklāt, atmaskot iepriekšējo paaudžu izglītības diskursu slēpto “dienas kārtību” un retoriku".

Ciktāl mēs veiksmīgi pildām šo "nebeidzamo uzdevumu", pedagoǵijas vēsture iegūst postmodernu pievienoto vērtību: tā dekonstruē, demitoloǵizē, un aptraipa "lielos", "varonīgos" un bieži vien pārspīlētos pagātnes stāstus, nevis lai izsmietu mūsu priekšgājējus, viņu izglītību vai viṇu ideālus, bet lai demonstrētu, ka arī viņi bija “cilvēciski radījumi”, kas dzīvoja konkrētā sociāli vēsturiskā kontekstā, no kā grūti abstrahēties. Tas raksturo lielos emancipatoriskos izglītības metanaratīvus un parāda, ka vismaz kopš 19. gadsimta pedagoǵija arvien vairāk atklāja pati savu dinamiku, kas, šķiet, nekādi negarantēja lielāku indivīda emancipāciju. Izglītības iespēju paplašināšanās automātiski nenodrošināja iespēju un autonomiju pieaugumu, bet spēja novest arī pie pakl̦autības un atkarības ${ }^{60}$. Herbstam ir pilnīga taisnība, atzīstot Tenorta prasību ${ }^{61}$ pētìt šo paradoksu "jaunajā" pedagogiijas "kulturālajā" vēsturē no iekšpuses - nevis ar konceptualizēšanu un struktūrām, ietvariem no ārpuses, t. i., vēstures vai socioloǵijas 
modeliiem. Un atkal Herbstam ir taisnība, kad viņš kopā ar Tenortu raksturo šīs "importa teorijas" kā viskritiskāko faktoru zināšanu trūkumā par ikdienas pedagogijas (klases realitātes) vēsturi, atzīstot, ka izglītîbai gandrīz vairs nav vietas pedagogíjas vēsturē ${ }^{62}$. Tas palīdz skaidrot vēsturiskās apziņas trūkumu skolotāju un pedagogu vidū. Tomēr pēdējā laikā saistībā ar ievērojamo spāņu pētījumu par skolas kultūru ${ }^{63}$ daži pētījumi tiek veltīti arī mācību stundu praksei $^{64}$. Taču pastāv liels jautājums, vai tie sniegs tādas atbildes, kādas skolotāji un pedagogi vēlētos dzirdēt.

Vēsturiskā demistifikācija, piemēram, par pedagoǵisko pētìjumu praktisko nozīmību vai par pedagoǵisko innovāciju ietekmi vienmēr, šksiet, kaitina un sanervozē ticīgos. Tādēl, pretēji Herbstam $^{65}$ (viņš šajā konkrētajā gadījumā paļaujas uz Džeraldīnes Klifordas ideju), es tiešām daudz neticu "pagātnes mācībām" vai "mācību stundām", ko vēsture sniegs par skolu reformēšanu ${ }^{66}$. Tāpat es neticu individuālai vai kolektīvai pedagoǵiskās pagātnes un iepriekšējās pieredzes privatizēšanai ${ }^{67}$. Protams, izglītības politikas veidotāji, tāpat kā skolotāju sagatavotāji ${ }^{68}$, noteikti turpinās izmantot "vēsturisko skatījumu, perspektīvi". Viṇi to dara galvenokārt tādēl, lai sekmētu, virzītu uz priekšu savas ieceres ${ }^{69}$. Nebūsim naivi, to apstiprina arī labējā virziena pedagogiijas vēsturnieces (konservatīvās politiķes) Dianas Ravičas jaunākā grāmata par progresīvās izglītības (ar tās "hedonistisko, individuālistisko, anarhistisko 60. gadu garu") nodarīto vēsturisko kaitējumu ${ }^{70}$.

Pedagoǵijas vēsture 21. gadsimta pedagogu auditorijā, manā skatījumā, būs nozīmīga tikai kā "patiesā daba", tas ir, kritiska, neērta, nekomfortabla"1 pat pret laika pārbaudi izturējušām patiesībām, piemēram, izglītības mērķiem "atturība", "pašdisciplīna" un "pazemība", ko Raviča grib iemācīties no pedagoǵijas vēstures ${ }^{72}$. Pedagoǵijas vēsture ir tālu no tā, lai būtu skolotājiem nepavism nevajadzīga, lieka greznība. Praktiskā pedagoga kompetence ietver kritisku refleksiju par savu darbību pagātnē un tagadnē, īpaši tagad, kad kritis normatīvās filosofijas ideoloǵiskais pārklājums. Kā norāda Toms Popkevics, "pedagoǵisko pētījumu koncepcijas kā mūsu veselā saprāta idejas par mācīšanu nevar tikt aplūkotas, it kā tās būtu dabiskas, bet tās ir jāeksaminē kā vēsturiski pieminekḷi sabiedrisko attiecību kontekstā" ${ }^{\prime \prime 3}$.

Mūsdienu Eiropas sabiedrībā ir iesakņojusies ideja par ekonomisko lietderību un izmaksu efektivitāti. Arī izglīî̄bas sektors nav izbēdzis no šī neolibrerālās ideologijas devītā viḷña. Pastāv uzskats, ka izglītības iestādēm jāspēelē "tirgus" un ar savu piedāvājumu jāieņem konkrēts segments vai niša. Kvalitātes kontrole tiek pārsvarā veikta, pamatojoties uz "klienta" apmierinātību, nevis kritisku refleksiju par to, ko vajadzētu sasniegt ar izglītības palīdzību. Izglītība tiek pasludināta par biznesu, kas piegādā zināšanas un prasmes (kārtīgi uzskaitītas kā sasniegumu līmeņi un attīstības mērķi un uzdevumi), lai nodrošinātu vietu darba tirgū. Neriskējot iesaistīties kultūrkritiskās debatēs par "izpildāmo prasību" nastas, kas tiek uzkrauta skolai, jēgu vai bezjēdzību, tomēr jāteic, ka šādu nostāju dominēšana draud novērst uzmanību no pedagogiijas kulturālās vēstures. Investīcijas vēstures pētījumā (arī pedagoǵijas vēstures) mūsdienās ir grūti samierināt, saskaņot ar domāšanu "menedžmenta" un "efektivitātes" kategorijās. Vēsture tā vietā, lai atzītu tik ļoti vēlamo tirgus domāšanu (kā prasība pēc "pel̦ņas" un izglītības "izmaksu-ieguvumu analīze"), piedāvā neērtu diskursu. Vēsturiskā pieeja kultivē praktiski nelietderīgā lietderīgumu. Tā cel aizsargvalni pret tūlītējā praktiskā labuma teroru.

No kultūrkritiskā viedokḷa distances, pētījums un izglītība vēsturē (arī pedagoǵijas vēsturē) izvirza mērķi iziet viņpus moderno laiku īsredzības, ieliekot to ǵenēzi garumgarā stāstā, kurā, iespējams, ir paradoksi ${ }^{74}$. Tâ, piemēram, vēlme pēc racionalitātes, kur prevalējošā prasība pēc praktiskā izmantojuma acīmredzami nav nekas vairāk kā izteiciens, ir saistīta ar modernizāciju, kam pamatus ir ielikusi pati skola tālā pagātnē. Ticēt ka, ignorējot vēsturi, būs iespējams izvairīties no sociālajiem procesiem, protams, ir rūgta ilūzija pat mācību plānu un programmu veidotājiem, pedagogiijas inovatoriem, politikas birokrātiem un tehnokrātiem, kuri pašreiz ir pagriezuši vēsturei muguru. 
Pārfrāzējot Nī̌̌i ${ }^{75}$, mūsu uzdevums ir un paliek konstanta samierināšanās ar eksistences vēsturiskumu, vienu no neērtībām, kas nekad neizzudīs no šìs pasaulīgās pasaules.

\section{Atsauces}

${ }^{1}$ ISCHE - Pastāvīgā starptautiskā pedagog̉ijas vēstures konference (International Standing Conference for the History of Education) - plašākā pedagogijas vēsturnieku apvienība, kas dibināta 1978. gadā un kurā darbojas nozares pētnieki no visas pasaules (tai skaitā Latvijas). ISCHE konferences katru gadu notiek citā valstī, pētījumi tiek publicēti žurnālā Paedagogica Historica (red. piez.).

$2 \breve{S}_{1}$ raksta angḷu variantā lietots apzīmējums history of education - izglīî̄bas vēsture, taču latviešu versijā izvēlējāmies lietot apzīmēju "pedagog̣ijas vēsture", kas Latvijā tiek izmantots plašāk (gan studiju kursu nosaukumos, gan publikācijās) (red. piez.).

3 J. Herbst, The History of Education: State of the Art at the Turn of the Century in Europe and North America, Paedagogica Historica, XXXV (1999) 737-747 (here 747).

4 Sk. M. Depaepe. A professionally relevant history of education for teachers: does it exist? Reply to Herbst's the State of the Art Article, Paedagogica Historica, XXXVII (2001) 631-640. Raksta pamatā ir šì publikācija. Sk. arī M. Depaepe. What Kind of History of Education May We Expect for the Twenty-first Century? Some Comments on Four Recent Readers in the Field. Essay Review in Memory of Maurits De Vroede (1922-2002) and Brian Simon (1915-2002): D. Crook \& R. Aldrich (ed.), History of Education for the Twenty-First Century; R. Aldrich (ed.), A Century of Education; P. Götte \& W. Gippert (Hg.) Historische Pädagogik am Beginn des 21. Jahrhunderts, \& T. S. Pokewitz, B. M. Franklin \& M. A. Pereyra (ed.), Cultural History and Education, Paedagogica Historica, XXXIX (2003) 187-199, kā arī autora rakstu spāņu val.: M. Depaepe. Vieja y nueva historias de la educación. Ensayos criticos. Barcelona, Octaedro, 2006.

5 Šis teksts ir prezentēts kā atklāšanas runa ATEE (Association for Teacher Education in Europe) Spring University 2008 konferencē Rīgā, Latvijas Universitātē 2008. gada 2.-3. maijā. Š̄is konferences tēma ir Teacher of the $21^{\text {st }}$ Century: Quality Education for Quality Teaching.

${ }^{6}$ M. M. Compère. L'Histoire de l'éducation en Europe. Essai comparatif sur la façon dont elle s'écrit. Paris/ Berne, INRP/Lang, 1995.

7 M. Depaepe. Entre pédagogie et histoire. Questions et remarques sur l'évolution des objectifs de l'enseignement de l'histoire de l'éducation, Histoire de l'Education, $\mathrm{n}^{\circ} 77$ (janvier 1998) 3-18.

8 R. Donato \& M. Lazerson. New Directions in American Educational History: Problems and Prospects, Educational Researcher, XXIX, 8 (November 2000) 4-15.

9 Herbst. The History, 738, šajā sakarā pārfrāzē H. E. Tenortu.

${ }^{10}$ Arī M. M. Compère. L'Histoire, 18 ff.; A. Nóvoa. L'histoire et l'histoire de l'éducation. In: A. Nóvoa. Histoire \& Comparaison (Essais sur l'Education). Lisbonne, Educa, 1998, $31 \mathrm{ff}$.

${ }^{11}$ S. Cohen. The History of the History of American Education: The Uses of the Past. In: S. Cohen. Challenging Orthodoxies: Toward a New Cultural History of Education. New York, Lang, 1999, 3-34.

${ }^{12}$ Sk., piem., IZEBF: Informationen zur Erziehungs - und Bildungshistorischen Forschung, Heft 3: Herbsttagung 1975: Aufgaben und methodologische Probleme historischer Forschung im Erziehungs- und Bildungswesen (1975); W. Böhm \& J. Schriewer (Hrsg.). Geschichte der Pädagogik und systematische Erziehungswissenschaft. Festschrift zum 65. Geburtstag von Albert Reble. Stuttgart, Klett-Cota, 1975; V. Lenhart (Hrsg.). Historische Pädagogik. Methodologische Probleme der Erziehungsgeschichte. Wiesbaden, Akademische Verlaggesellschaft, 1977.

${ }^{13}$ M. Depaepe. On the Relationship of Theory and History in Pedagogy. An Introduction to the West German Discussion on the Significance of the History of Education. Leuven, Leuven University Press, 1983.

${ }^{14}$ Sk. B. Rang. Pädagogische Geschichtsschreibung in der DDR. Entwicklung und Entwicklungsbedingungen der pädagogischen Historiographie 1945-1965. Frankfurt/Main, Campus Forschung, 1982; M. Heinemann (Hrsg.). Historische Pädagogik in Europa und den USA. 2 vol. Stuttgart, Klett-Cota, 1979-1985.

${ }^{15}$ J. Herbst. The International Standing Conference for the History of Education after the first decade, Paedagogica Historica, XXVI (1990) 85-89; M. Depaepe. International Standing Conference for the History of Education (ISCHE). In: P. Caspard (dir./ed.). Guide international de la recherche en histoire de l'éducation/ International Guide for Research in the History of Education. Bern/Paris, Lang/INRP, 227-232. Sk. arī M. Depaepe. It's a long way to... an international social history of education. In search of Brian Simon's legacy in today's educational historiography, History of Education, XXXIII, 5 (2004) 531-544.

${ }^{16}$ Sk., piem., K. Salimova \& E. V. Johanningmeier (eds.). Why should we teach history of education? Moscow, The Library of International Academy of Self-Improvement, 1993. 
${ }^{17}$ K. Salimova. Educational Wisdom of the Past: A Message for the Future. In: Salimova \& Johanningmeier, Why should we, 104-106.

${ }^{18}$ M. Depaepe. History of Education Anno 1992: 'A tale told by an idiot, full of sound and fury, signifying nothing?’, History of Education, XXII (1993) 1-10.

${ }^{19}$ Mistifikācija - šajā gadījumā apzināta maldināšana, pārdabiskuma piedēvēšana (red. piez.).

${ }^{20}$ Hagiogrāfija - baznīcas vēstures literatūra, kanonizēto garīgo un laicīgo personu dzīves apraksti (red. piez.).

${ }^{21}$ M. Depaepe \& H. Van Crombrugge. Using or Abusing the Educational Past? Some methodological reflections on the place of Johann Heinrich Pestalozzi in the educational historiography. In: H. Gehrig (ed.). Pestalozzi in China. International Academic Symposium on the Occasion of the Publication of Johann Heinrich Pestalozzi's Selected Works in Chinese. Beijing, 10-14 October 1994. Zürich, Pestalozzianum, 1995, 51-62; M. Depaepe. My way to the new 'cultural' history of education: from 'historical pedagogy' to the history of 'educational mentalities'. In: J. H. Coetzee \& T. G. Smith (eds.). International conference on education and change. A selection of papers of a conference held in September 1995 at Unisa, Pretoria. Pretoria, University of South Africa, 1996, 1-11.

${ }^{22}$ Sk., piem., J. H. Jordaan. How a course in the history of education serves as a changing factor in the education and lives of first year students. In: Coetzee \& Smith (eds.). International Conference, 259-263.

${ }^{23}$ Sk. Zhang Zijonga ziņojumu par konferenci Paedagogica Historica, XXXI (1995) 310-312.

${ }^{24}$ Citēts no Ren Zhong Yen, Pestalozzi and Modern Education. In: Gehrig, Pestalozzi, 111. Yuan Rui, Pestalozzi and Modern Activity Teaching, id., 116. Zhou Huiying, Johann Heinrich Pestalozzi on Labour Education His Theory and Practice, id., 121. Sun Jianguo, Integration of Education and Productive Labour - Through Offering Courses of Labour Techniques as the Main Channel, id., 125; Teng Dachun, Carry Forward Pestalozzi's Dedication to Education - in Commemoration of his 250th Birthday, id., 83.

${ }^{25}$ J. H. Jordaan. Schooling in Changing African Societies: Before and after Independence, 1950-1996. In: C. Majorek \& E. V. Johanningmeier (eds.). Educational Reform in National Perspectives: Past, Present and Future. Cracow, Polish Akademy of Sciences Publishing House in Cracow, 2000, 137-148 (Quotation: 146).

${ }^{26}$ Sk. M. Depaepe. Normatief-pedagogisch denken in Vlaanderen. Continuïteit en discontinuïteit in de katholieke pedagogiek sedert 1918. Pedagogische Verhandelingen, X (1987) 270-291; Idem, De spanning van verborgen agenda's. Ontwikkelingen inzake het onderwijs in de historische pedagogiek, Comenius, XVII (1997) 200-215, kur lasītājs var atrast atsauces uz De Hovre un Decoene darbu orǵināliem.

${ }^{27}$ Sk. M. Depaepe. De marxistisch-leninistische opvatting over historische pedagogiek in de D.D.R. (ca. 19651980), Pedagogische Studiën, LIX (1982) 507-518, kurā atrodams darbu saraksts par šī laika Austrumvācijas diskusijām.

${ }^{28}$ Mutatis mutandis (latīṇu val.) - tiks izmainīts, ko nepieciešams izmainīt (red. piez.).

${ }^{29}$ Sk. R. Lowe. History as Propaganda: The strange uses of the history of education. In: P. Gordon \& R. Szreter (eds.). History of Education: The making of a discipline. London, Cass, 1989.

${ }^{30}$ Kas padara K. Salimovas idejas saprotamas pat pēc perestroikas. Sk. K. Salimova, Educational Wisdom.

${ }^{31}$ Sk. I. Kestere. The use of textbooks in the history of education. The experience of the University of Soviet Latvia from the 1940 s until the 1980s. Paper presented at the $11^{\text {th }}$ Conference of the Internationale Gesellschaft für Historische und Systematische Schulbuchforschung. Ypern, 5-6/10/2007.

32 J. H. Stoutemeyer. The Teaching of History of Education in Normal Schools, School and Society, XVII, 177 (1918) 571-573.

${ }^{33}$ L. A. Cremin. The Recent Development of the History of Education as a Field of Study in the United States, History of Education Journal, VII (1955) 1-5.

${ }^{34}$ E. P. Cubberley. The History of Education: Educational practice and progress considered as a phase of development and spread of western civilization. London, Constable, s.d. [1920]; E. P. Cubberley. Public Education in the United States. Cambridge, MA, Riverside Press, 1919.

${ }^{35}$ L. A. Cremin. The Wonderful World of Ellwood Patterson Cubberley. New York, Columbia University, 1965.

${ }^{36}$ Vigi - politiska partija Lielbritānijā 17.-19. gs., Liberālās partijas priekštece (red. piez.).

${ }^{37}$ F. Lilge. The Functionalist Fallacy and the History of Education, School and Society, LXV, 1648 (1947) 241-243.

${ }^{38}$ B. Baylin. Education in the Forming of American Society: Needs and Opportunities for Study. Chapel Hill, University of North Carolina Press, 1960, 14.

${ }^{39}$ History of Education Society. 
${ }^{40}$ History of Education Quarterly.

${ }^{41}$ E. B. Wesley. Lo, the Poor History of Education, School and Society, XXXVI (1933), 619-621.

${ }^{42}$ E. B. Wesley. Lo, the Poor History of Education, History of Education Quarterly, IX (1969), 342.

${ }^{43}$ No angḷu val. present - 'tagadne', šajā gadījumā - tagadnei obligāti piesaistīts (red. piez.).

${ }^{44}$ Evaņgēēisms - sekošana kādas doktrīnas pamatprincipiem (red. piez.).

${ }^{45}$ Sk. S. Cohen. The History, 22, originally from B. Bailyn, Education, 9.

${ }^{46}$ Donato \& Lazerson. New Directions, 6.

${ }^{47}$ D. Ravitch. The Revisionists Revised: A Critique of the Radical Attack on the Schools. New York, Basic Books, 1978.

${ }^{48}$ Sk., piem., D. R. Warren. A Past for the Present: History, Education and Public Policy, Educational Theory, XXVIII (1978) 264-265.

${ }^{49}$ J. Herbst. Beyond the Debate over Revisionism: Three Educational Pasts Writ Large, History of Education Quarteerly, XX (1980) 131-145.

${ }^{50}$ D. Ravitch \& M. A. Vinovskis (eds.). Learning from the Past. What History Teaches Us about School Reform. Baltimore, The John Hopkins University Press, 1995.

${ }^{51}$ Sk. arī R. Aldriha kritiku par "britu situācijas” izpratni: R. Aldrich. Lessons from History of Education. The selected works of Richard Aldrich. London/New York, Routledge, 2005.

${ }^{52}$ Anglu val. - new "cultural” history of education.

${ }^{53}$ K. Jarausch. The Old 'New History of Education': a German reconsideration, History of Education Quarterly, XXVi (1986) 225-241.

${ }^{54}$ S. Cohen. The History, 19.

${ }^{55}$ Piem., S. Cohen. Representations of History in the Linguistic Turn. In: S. Cohen. Challenging Orthodoxies, $65-85$.

${ }^{56} \mathrm{~K}$. Brehony. From the particular to the general, the continuous to the discontinuous: progressive education revisited, History of Education, XXX (2001) 413-432; Sk. arī kritisko grāmatas apskatu Sol Cohen's Challenging Orthodoxies by H. E. Tenorth, Linguistic Turn und Konstruktionsmetaphern, Zeitschrift für Pädagogische Historiographie, VII (2001) 134-137.

${ }^{57}$ R. Lowe. Postmodernity and Historians of Education: A View from Britain, Paedagogica Historica, XXXII (1996) 307-323 (Quotation: 323).

${ }^{58}$ A. Escolano. Postmodernity or High Modernity? Emerging Approaches in the New History of Education, Paedagogica Historica, XXXII (1996) 325-341 (Quotation: 340).

${ }^{59}$ M. Depaepe. Demythologizing the Educational Past: An Endless Task in History of Education, Historical Studies in Education/Revue d'histoire de l'éducation, IX (1997) 208-223.

${ }^{60} \mathrm{M}$. Depaepe. Educationalisation: A key concept in understanding the basic processes in the history of Western education, History of Education Review, XXVII, 2 (1998) 1-15.

${ }^{61}$ H. E. Tenorth. Lob des Handwerks, Kritik der Theorie - Zur Lage der pädagogischen Historiographie in Deutschland, Paedagogica Historica, XXXII (1996) 343-361.

${ }^{62}$ M. Depaepe \& F. Simon. Is there any Place for the History of 'Education' in the 'History of Education'? A Plea for the History of Everyday Educational Reality in- and outside Schools, Paedagogica Historica, XXXI (1995) 9-16.

${ }^{63}$ A. Esscolano Benito. Las culturas escolares del siglo XX. Encuentros y desencuentros, Revista de Educación, núm. Extrordinario (2000), 201-218.

${ }^{64}$ I. Grosvenor, M. Lawn \& K. Rousmaniere (eds.). Silences \& Images. The Social History of the Classroom. New York, Lang, 1999; M. Depaepe et al. Order in Progress. Everyday Educational Practice in Primary Schools - Belgium, 1880-1970. Leuven, Leuven University Press, 2000.

${ }^{65}$ J. Herbst. The History, 747.

${ }^{66}$ Sk. arī M. Depaepe. Some statements about the nature of the history of education. In: Salimova \& Johanningmeier (eds.). Why should we, 31-36.

${ }^{67}$ G. McCulloch. Publicizing the educational past. In: D. Crook \& R. Aldrich (eds.). History of Education for the Twenty-First Century. London, Institute of Education University of London, 2000, 1-16.

${ }^{68}$ Sk., piem., autora kritisko apskatu par J. Wolfe Learning from the Past. Historical Voices in Early Childhood Education. Mayerthorpe, Piney Branch Press, 2000: M. Depaepe. Ein Beispiel klassischer Hagiographie, Zeitschrift für pädagogische Historiographie, VII (2001) 57-58.

${ }^{69}$ Donato \& Lazerson. New Directions, 9. 
${ }^{70}$ D. Ravitch. Left Back. A Century of Failed School Reforms. New York, Simon \& Schuster, 2000.

${ }^{71}$ Depaepe, Demythologizing.

${ }^{72}$ D. Ravitch. Left Back, 407 \& 453.

${ }^{73}$ T. S. Popkewitz. The Denial of Change in Educational Change: Systems of Ideas in the Construction of National Policy and Evaluation, Educational Researcher, XXIX, 1 (January-February 2000), 17-29 (Quotation: 27).

${ }^{74}$ Sk. M. Depaepe, F. Simon \& A. Van Gorp (eds.). Paradoxen van pedagogisering. Handboek pedagogische historiografie (Leuven/Voorburg, 2006²).

${ }^{75}$ Sk. M. Depaepe. Gesplitst en gespleten. De kloof tussen wetenschappelijke en praktische kennis in opvoeding en onderwijs. Leuven/Leusden, 2002, kura pamatā ir F. Nietzsche. Vom Nutzen und Nachteil der Historie für das Leben (1874).

\section{Summary}

The article "Qualities of Irrelevance in the Training of Teachers of the History of Education" deals with development of history of education as a discipline in close connection with history of education as a study course in the teacher training programmes. The main issues addressed in the article are: "what kind of the history of education was taught and does it still have the potential to attract educationalists today?" The author opposes aspirations to make the history of education "relevant" in solving contemporary practical problems and making forecasts for future policy or in legitimizing traditional values. Politicalization and ideologization of the history of education by the church and the state also are unacceptable. The problems inside of history of education as a discipline reflect themselves in the history of education as a study course. The article analyses the reasons of the low popularity of the study course till the World War II when the "paradigm shift" and the revisionism of the 60s (L. Cremin, B. Beilin) opened wider sociocultural perspectives for history. The 80 s are characterized by a "new" cultural history of education, but the post-modern era comes with the "endless task" of writing and rewriting history: it deconstructs and demythologizes stories of the past. Today, when education has become a business, the historical approach cultivates the utility of the non-utilitarian. It sets itself up as a dam against the "terror" of the immediate practical benefit.

Keywords: history of education as a discipline; history of education as a study course; teacher training programmes. 


\title{
TEACHER TRAINING FOR SPECIAL EDUCATION AND INCLUSIVE EDUCATION - A CONTRADICTION? VAI PASTĀV PRETRUNA STARP SKOLOTĀJU GATAVOŠANU SPECIĀLAI IZGLİTĪBAI UN IEKL,AUJOŠAI IZGLĪTĪBAI?
}

\author{
Thomas Hofsäss \\ Leipzig University
}

\begin{abstract}
An inclusive orientated school needs teaching stuff with profound knowledge and skills for pupils with special educational needs. Teachers have to be prepared for a new role and task in a school, which makes part of the European "Education for All" movement. The key issue is therefore teacher training that has to develop teachers' skills and attitudes more educational. This results also in a reform of teacher training curricula and structure.
\end{abstract}

\section{Introduction}

Not least stimulated by the discussion about inclusion, equality and fairness of opportunity in education, but also stimulated by the socio-legal roots of disabled peoples' active social participation in public life, a question arises: how are these aspects implemented in education and, consequently, teacher education? Without a doubt, all EU member states are by now advocating the unlimited right to school education for all children and youths regardless of their type of disability or impairment. This, in itself, is a historical milestone, and one that has not yet been reached for many children and youths in other countries. At the same time, the right to education for all is never officially questioned in democratic societies; the question to what extent this is actually implemented is another matter. Regarding a global-scale comparison, the formal situation of "Education for All" is hence solved within the EU. As formulated by The European Agency for Special Educational Needs as early as in 2003:

"The current tendency in the EU is to develop a policy towards inclusion of pupils with SEN into mainstream schools, providing teachers with varying degrees of support in terms of supplementary staff, materials, in-service training and equipment." (Meijer, 2003)

Three approaches are currently prominent on the level of school and educational systems, each of which claims to lead the path to active participation for people with disabilities and impairments. The "one-track approach" is considered to be highly efficient in this respect.

The First (one-track) approach unites countries that develop a policy and practices geared towards the inclusion of almost all pupils within mainstream education.

The Second (multi-track) approach contains a multiplicity of approaches to inclusion. They offer a variety of services between the two systems (i.e., mainstream and special needs education systems).

The Third (two-track) approach is based on two distinct education systems. Students with SEN are usually placed in special schools or special classes. These systems are (or at least, were until very recently) under separate legislation, with different laws for mainstream and special needs education.

These approaches correspond to the approaches to teacher education. Each of them is undergoing significant change, and each of them aims at the same target, a target that is a weapon itself: inclusion. The mission, however, gets more intense when the question about the specific understanding of inclusion that the strategy is based on needs an answer. 
In order to develop the thought from an anthropological perspective, the understanding of inclusion may be classified as a four-step evolution:

$\diamond$ Educational exclusion: exclusion of all individuals who fail to achieve a general school or performance standard, or who do not gain access to schooling due to their preconditions, with the consequence that no educational services are devised.

$\diamond$ Educational segregation: exclusion of all individuals who fail to achieve a general school or performance standard, or who do not gain access to schooling in terms of a general school (mainstream) due to their preconditions, with the consequence that a parallel system is put to work (special stream), in which the attempt of adapting to the students' abilities is made. Pre-school, attached and post-school institutions are connected herewith. The basis for assignment to the special stream schools is individualized assessment procedures, which legitimate the student as incapable of achieving mainstream norms and conditions. The responsibility for the failure at mainstream education is interpreted in the sense of a relief function. The theoretical model claiming that homogenous groups learn most effectively is founded on this causality.

$\diamond$ Educational integration: identification and definition of all individuals who fail to achieve a general school or performance standard, or who do not have access to the standard's fulfilment. They are, however, physically and didactically integrated via the creation of specific learning and developmental settings within the mainstream system, which the non-impaired students may also profit from. As integrated students, they fulfil the positive school-systemic effect of causing the improvement of the general school's equipment, as integration is always seen as a school resource. As a consequence of the labelling-resource dilemma, integrating systems tend to count a higher number of students with special educational needs than segregating systems.

$\diamond$ Educational inclusion: all students, with all levels of abilities, attend one and the same school (physical inclusion), with the twist that neither the educational nor the special educational needs are regarded as exceptional. There is an individual learning and development plan for each child, along the lines of which he/she is taught. This may even lead to the dissolution of borders of the grade (mixed-age learning) or, in the case of sameage learning, to a consistent composition of the learning group throughout up to ten years of schooling, regardless of the individual level of learning and development. If anything, there may be a curricular framework. The inclusive school is also closely connected to the local community: it is, at the same time, a communal space.

Comparing these four steps to other social areas, the similarity between them and socio-legal programs emerge when it comes to the handling of minorities, e.g., under the heading of "integration policy." Additionally, these four steps record a process of historical development that necessarily displays developmental irregularities or differences. In countries which had a differentiated special education system at their disposal at an early stage, the changeover to the inclusion-centred school needs to be interpreted differently than in countries that were only capable of providing a basic educational system within the past fifty years.

This is likely to be at the core of the conflict that is inherent in the discussion about processes of transformation: the central-European countries such as Poland, the Czech Republic, the Baltic States, but also Germany, historically have the longest-running experience in the overall schooling of students with various types of disabilities. This generates an educational tradition that is very resistant to further development.

\section{The position of teacher training}

This preview will have made the point that, in the wake of general education, teacher education is also engaged in several processes of change and conflicts of legitimacy where it concerns 
students with special needs. This again is closely related to the corresponding traditions and institutions of teacher education and the global challenges implied by the future development of the education system, which, in their turn, can only be vaguely defined. However, one basic belief is seemingly shared on a global scale: investments in education can trigger economic prosperity. The higher the population's average educational degree, the better the economy's perspective chances of growth. Teachers are seen as the propelling force of that development, while they are themselves involved in a conflict with their own experiences and convictions as well as with what may be expected of them in the future. Put in the perspective of students with educational and special needs for support, this translates into another dilemma: the educational systems' resource control, too, relies on the efficacy of investments in education.

The current trends of teacher training may be described along three paradigms, of which some are competing internally:

- the professionalism aspect as accentuated by special education: specific knowledge about and for the diversity of children with needs for special educational support;

- the ethically accentuated equality aspect: students with needs for special educational support must be treated equally to children without these needs;

- the inclusion approach as accentuated by social and educational policy: the educational system has one and the same form for all students, which is why there is a need for one teacher who has all the competences - inclusive education by an inclusively trained teacher.

Contradictions, confusions, but also similarities emerge from all this pattern of paradigms. The similarities are determined by the dilemma that has been accepted in most European educational systems by now: that children's education is not yet based on sufficient skills of teachers, and that the questions for a need thereof and whether all children and youths, after all, do have a claim for education, are not being asked. But what does "professionalism" mean in a context that is at first hand forced to console many different foci of interest?

The underlying question is whether specialist training or an overall training of a teacher who is able to effectively act pedagogically in varied conditions is required. The background of this question is the process of transformation from a teacher to pedagogue.

\section{The term "special educational needs"}

This professional debate is always to be seen in relation to the entirety of the system as it is currently focused; but not as a free ticket to a different educational system, which is how the perspective of inclusion is sometimes misunderstood: as the gateway to a systemic change. Neither multi-pedagogues nor the abolition of specialists will bring about that change. How, then, can it be introduced? Let us turn to the major pedagogic tasks a teacher has to fulfil if he/she has students with needs for educational and special educational support in his/her class. Regardless of what types of students the class consists of, they should be asked the following basic questions:

What are the lessons like?

Where does the child live?

What story does he/she bring to the classroom?

What fears and wishes determine his/her actions?

What is his/her topicality?

What is he/she currently overstrained with?

What is he/she supposed to learn?

Which options do I have for creating this child's life and development chances? 
Competences in learning assessment are the relevant key in order to draft an individual learning and development plan, which is independent of the location of learning and individually related to the student. If we focus on the first question, we can encounter a difficulty: what are special educational needs? Is it the mainstream school system itself that creates these special educational needs as well? The term certainly means more than for an individual to be the carrier of a disability. It suggests that children or youths, in the absence of additional support systems, are facing the risk of not developing as expected, thus not taking their designated position in society. This fact demonstrates the ordeal of norms, which is ever-manifested even in democratic and inclusion-oriented societies. From a pedagogic point of view, this is only of secondary interest, while the primary question would be: How can I describe the preconditions for a student's learning situation and relate it to individual and curricular development goals? The answer may come much easier if the curricular goals are understood to be less binding and limiting, since this perspective will put forward the individual support of learning and development within academic plans of action.

The certainly flamboyant, heterogeneous nature of the term "special educational needs" can be demonstrated by a look at school statistics. There are great differences among certain statistical values: On the one hand, it is surprising that in Finland, 17\% of all students are described as students with special educational needs; on the other hand, there are rates of less than $2.5 \%$ in other countries (Meijer 2003). This may be a result of different school systems, but also of categories. While in a number of countries, students with severe learning impairments are counted among the students with special educational needs, these students are simply categorised as educational needs students in other countries: as students with no particular need for support. In correlation with the percentage of students who leave school without a degree, it appears that those countries who support as few special needs students as possible, or which do not even dispose of respective support resources, are markedly standing out. This culminates in a dilemma: Countries which strongly differentiate their school system tend to have a lower rate of students who do not reach a degree, while countries that hardly differentiate their school system, and accordingly do not offer specific support, generate a higher percentage of students who fail to graduate. This clarifies that in a framework of teacher education, regardless of the type of the school system, basic knowledge on issues of learning and developmental diagnostics, individual learning and developmental planning, counselling and differentiated teaching is essential.

If the goal is the European perspective of "Education for All", based on each student's learning situation, then educational standards are obligatory. These standards should describe the basic conditions of the school and educational system, the support approaches and the structure of teacher education. A model of adapted teacher education therefore should be, at its core, diversity-based, regardless of the individual focalisation.

\section{Diversity-based teacher training}

Any teacher education based on diversity will have to take into account the following features of diversity, which may be variably relevant depending on age, but which would have to mark the foundation of standards for teacher education:

- differences in the individual learning situation and learning competence;

- socio-cultural, as well as socio-economical differences concerning experiences of socialisation;

- differences in experiences of migration;

- experiences that differ from a reliable social structure (familiar and extra-familiar);

- differences resulting from gender and gender role specificity.

- differences manifested in the bio-social and also disability-related learning competences. 
In practice, teachers are struggling with these differences, which are expressions of diversity under the flag of equality. This issue originates from the traditional teacher education's ongoing assumption of equality in the sense of equal learning competences and preconditions being the starting point of school learning, an equality that serves as the basis for the preferred homogeneous learning concept. This homogeneous learning concept, however, leads to the possibility of school system sanctions being triggered by positive as well as by negative deviations from a medium norm: high competence- and giftedness-related resources, but also resources identified as insufficient, have inadequate development prospects in a school system which is analysed from the perspective of a performance medium. This is very often supported by curricular demands and frequently executed external evaluations (comparative work assignments), which help cement this concept of medium norms.

This analysis shows that teacher competences reach their limits at the same point where school-systemic norms have a regulating impact on output expectations. Simultaneously, this serves as an act of defence put forward by teachers who hesitate to implement certain teaching methods, in particular, student-centered teaching and learning methods, which are regarded to be rather complex. Teacher education is also focused on this type of behaviour, since it would otherwise have to question its own forms of mediation.

This dilemmatic pattern is, to no lesser extent, posed to the inclusion-centred concept of school and education, which is also determined by the mainstreaming paradigm. The latter tempts us into interpreting individual development plans as the grouping of students diagnosed with similar learning conditions, and assuming that shared learning on the same subject is likely to be focused on areas less crucial to school performance. Even in the subject of teacher education, the assumption that shared learning works particularly well in sports and musical lessons is overemphasized. This, however, would imply that the same concept is less successful in other areas such as mathematics or languages; the concept of extra-streaming is accordingly frequented there.

Do we, then, need specialised teachers? Or will a didactically broadly educated teacher be able to do an equally good job?

A realistic look on the tasks teachers at an inclusion-centred school are facing quickly proves that the concept of the teacher profession is in need of a directional decision which would have to be implemented within the framework of social policy. The decision in question is: Is the teacher of the future going to continue to be a subject teacher, whose competence is primarily subject-related, or is he going to be a pedagogic specialist who is able to accompany students appropriately in pedagogic as well as professional terms? Transferred to the field of medicine, the question would be: do we need a doctor with a competence of action in all medical areas, or do we need doctors with core competences in one specialised discipline?

\section{Conclusions}

A look into the history of teacher education and the image of the teacher profession shows that this new discussion is one that questions the conventional development of teacher competences. At the onset of the general education system, the teachers who were recruited were those who deemed themselves capable of combining all the skills and competences, both pedagogic and subject-related. Those were teachers facing very heterogeneous learning groups, since the idea of general education needed to be channeled into a structure and a system first. The teachers' orientation on subject disciplines made a canon possible, which also generated the need to combine the culturally and socially necessary knowledge, which, in turn, triggered a sustained economic development. Today, in comparison, we have a wealth of highly specialised pedagogic and professional knowledge and highly specialised education systems and curriculums. 
Knitting both spheres together in an inclusion-centred school is a meaningful step. Cooperation between both competences may serve for the mastering of the task of supporting the output under the provision of individual learning and development planning, hence displaying educational justice. As far as teacher education is concerned, this would mean building close links of collaboration between subject disciplines, subject didactics and special educational disciplines in order to inform prospective teachers that educationally just, shared learning is empowered by the cooperation of specialised and pedagogically oriented teaching staff. The challenge for teachers educators, accordingly, is to be the first to deal with and live in this cooperation.

\section{References}

Ainscow, M. \& Booth, T. \& Dyson, A. (2006) Improving Schools, Developing Inclusion. New York: Routledge.

Bartolo, P. (Ed.) (2007) Responding to Student Diversity. A Teacher Handbook. Malta: University of Malta. http://www.dtmp.org.

Booth, T., \& Ainscow, M. (2002) Index for inclusion: Developing learning and participation in schools (Rev. ed.). Bristol, UK: CSIE http://inclusion.uwe.ac.uk/csie/indexlaunch.htm.

Meijer, J. W. (Ed.) (2003) Summary Report: Inclusive Education and Classroom Practice. European Agency for Development in Special Needs Education (www.european-agency.org)

Prengel, A. (2006) Pädagogik der Vielfalt. Wiesbaden: VS Verlag für Sozialwissenschaften.

Peterson, J. \& Hittie, M. (2003) Inclusive teaching. Creating effective schools for all learners. Boston: Pearson Education.

Sander, A. (2004) Konzepte einer Inklusiven Pädagogik. In: Zeitschrift für Heilpädagogik 5, S. 240-244.

Spencer, J. S. (2001) Creating Inclusive Classrooms. Effective and Inclusive Practices. Upper Saddle River: Merrill Prentice Hall.

UNESCO (1994) The Salamanca Statement and Framework for Action on Special Needs Education, World Conference on special Needs Education. Paris: Author. http://www.unesco.org/education/pdf/ SALAMA_E.PDF.

UNESCO (2004) Changing teaching practices using curriculum differentiation to respond to students' diversity. Paris: Author. http://unesdoc.unesco.org/images/0013/001365/136583e.pdf.

\section{Kopsavilkums}

Iekļaujošai skolai ir nepieciešami skolotāji, kas apguvuši attiecīgas zināšanas un prasmi strādāt ar skolēniem, kuriem ir speciālas izglītības vajadzības. Skolotājam ir jābūt labi sagatavotam profesionālam darbam. Viñam ir jauna loma skolas uzdevumu veikšanā, un tā ir aplūkojama kā Eiropas kustības "Izglītība visiem" sastāvdaļa. Tādēl šajā publikācijā galvenā uzmanība pievērsta skolotāju izglītībai, kas spētu nodrošināt skolotājiem prasmes un attieksmes pilnveidošanos, uz tā balstās skolēnu ar īpašām izglīīības vajadzībām audzināšana. Šis process paredz skolas reformēšanu, skolotāju izglītības satura un struktūras maiņu.

\section{About the author}

Prof. Dr. Thomas Hofsäss, full professor for Special Education/Learning Disabilities Education at the Faculty of Education, Leipzig University.

E-mail: hofsaess@uni-leipzig.de 


\title{
TEACHERS AS RESEARCHERS IN THE ERA OF TESTS SKOLOTĀJI KĀ PĒTNIEKI TESTU LAIKMETĀ
}

\author{
Irēna Žogla \\ The University of Latvia \\ "Life in culture is ... an interplay between the versions \\ of the world that people form under its institutional sway \\ and the versions of it that are products of their individual histories" \\ J. Bruner (1996, p. 14).
}

\begin{abstract}
Changes in education since the end of the 80 -ies of the $20^{\text {th }}$ century have brought innovations to our schools, which are still steering changes in pedagogical process and teacher education. Educators and teachers still borrow ideas from other countries and by doing so bring considerable changes to schools. Many experiences have entered our educational systems without appropriate modifications to match the socio-cultural context.

Some current essentialities of educational research and research as a component of teachers' professional activities are being addressed: problems of testing, the existing practices of testing which are poorly linked to the process of learning. Teachers are often oriented towards the procedure of testing instead of the quality of learning. To alter this practice, in-depth research is needed aiming at sound and effective forms of accountability, which could provide an adequate picture of schooling, facilitate and reflect the quality of individual learning and, as a consequence, also the quality of the learners' achievements.

Multiple researches in education and about education are still in process. The uncertainty about the object of educational research leads to uncertain conclusions; therefore, the implementation of research results is limited. The article includes an introduction into the categories research in education and research about education.

Widely practiced tests exert power; therefore, research is needed to make pedagogy move from teachers' instruction to learners' activity; hence, several considerations are suggested for the discussions on what a good investigation conducted by teachers could be, as well as several characteristics are mentioned which distinguish it from every-day problem-solving and random observations.
\end{abstract}

Keywords: research as a component of teachers' professionalism, qualities of teachers' research, regularities and multiple dynamic links.

\section{Introduction}

Just devote some minutes to the following questions: What is it there in our schools that does not satisfy me? Can my efforts make my school better? You will, certainly, come to some more questions: What changes have taken place recently, and how do they interfere with teachers' experience and pedagogy? How can I know whether my pedagogy is good and to what extent my learners' achievements depend on it? What and how shall I investigate my learners' achievements, their development, or how can I estimate my pedagogical competence? The questions themselves include a common desire - we all would like to have more balance in our professional field to achieve more.

There is no doubt many of us would like their life at school to be more stable and clear. For several years my master students who are at the same time teachers at schools gave almost the same answers - we need clarity, stability, certainty which would bring some balance into schools to feel comfortable at work. To all of us, stability means economically, politically, and professionally well-prepared and smooth transition of paradigms, fulfilment of professional ambitions, justice, welfare, productive communication and cooperation with the learners and their parents. 
In a post-modern society, especially one in transition, as Latvia is, the lack of stability results from economics, educational policy, intercultural dialogues, and it takes different forms to be reacted to in schools, as well as brings imbalance into schools.

Since 1991, several novelties entered our schools: self-evaluation, developmental planning, attestation, accreditation, and, certainly, testing. We introduced testing to make assessment objective, and it turned into a means of keeping self-confidence of teachers and schools, as well as the learners' individual paths of learning under some sort of control. At least two requirements influence educational practice: the requirements of the state institutions, for instance, standards (societal level), and initiatives of the local bodies (disciplinary demands towards schools of the area). Meanwhile, individual preferences, values, teachers' abilities, and learners' personal needs should function as sources of goals. Thus, the balance/nonbalance between societal, institutional or bureaucratic, and individual values and needs on the one hand, and teachers' competent functioning, on the other hand, experience constant influence: this balance is facilitated, violated, or ignored. Hence a dilemma: societal orientation in a democratic, learner-centred school should have initiated teachers' creativity, while the institutional accountability tests have strongly moved education toward institutional goals and a kind of control. Teachers' individuality and responsibility, therefore, confronts a certain normative domain. Even more - the growing diversity of population is confronted to institutional pressures, which push learners of different cultures and individual styles as well as their perspectives toward common goals (tests are supposed to assure these goals), and does it to a certain extent in a formal way.

By now our teachers are not supplied enough with tools that help them follow common targets, reach common goals and at the same time are supportive towards teachers' and learners' individual abilities, values, perspectives. In this situation, teachers' initiatives confront a possibility of their learners' failure at the final tests. Actually, we lack institutionally recognised and sound options adopted by teachers of final testing that meet an individual needs as well as facilitate the development of individualities. Therefore, this unsolved dilemma is violating humanistic, learner-centred pedagogical process and, due to it, also learners' individual development. Even more, the existing practices of testing poorly link to the process of learning-during the lessons, teachers often orientate themselves towards the procedure of testing instead of quality of learning.

The current practices of testing not only strongly affect classroom teaching-learning, but also public views of teachers and schooling. If asked, teachers almost unanimously answer that there is something wrong with the practices of testing, which bring destructive contradictions into pedagogical settings.

"In addition to improving normative tests, we should consider encouraging the students to pursue their interests and talents at some depth ... Despite the desire for options, we need common goals and measures to identify and fix inadequacies and inequities. Yet when limited, these accountability indicators have dramatic effects on teaching and learning" (Baker, 2007, 310). Captured by requirements and severe instructions, teachers feel themselves forced to shorten the time for in-depth and strategic learning.

To alter this practice, we need vast research (professional) and teachers' everyday investigations. Therefore, we have to address several areas to introduce sound and effective forms of accountability, which could provide an adequate picture of learners' learning-centred schooling, approve teachers' choices, and, by doing so, make testing educative:

- facilitate and reflect the quality of individual learning and, as a consequence, also the quality of the learners' achievements;

- distinguish between the essence of the constant regularities of a learner-centred learning-teaching, which make the pedagogical process exist, and flexible choices or 
instructional dynamics of specific classes, which teachers create to assist learning and investigate the learners' achievements dependent on these dynamics;

- by measurements facilitate and reflect individuals' ability to transfer their knowledge and strategies to new contexts of usage and self-evaluation;

- encourage the development of the learners' many-sided abilities in accordance with their actual and perspective needs;

- strongly follow the logic of assessment within a learning-centred process: distinguish achievements, spot what should be improved, formulate options to achieve more, and offer teachers' assistance if and when needed;

- introduce innovative changes into the programmes of teacher education and further professional development to foster the development of the learners' individuality.

Vast research means national projects leading to sound and constructive conclusions on teachers' professional development to conduct a learners' learning-centred process, and, against this background, to adequate pedagogical tools which integrate the content and strategies of learning-teaching, measurement of the learners' benefit, as well as possibilities and challenges of the environment.

Teachers' every-day observations should grow into constant research to provide not only immediate feedback within the instructional dynamics, but also a sound background by distinguishing regularities of a pedagogical process for teachers' and learners' targeted option which initiate the learners' activities and foster their individual pace of development.

\section{Shortly on international practices}

The USA have a long-lasting experience of using tests, therefore their researchers' views on testing and educational investigations might help us understand priorities and limits of testing. Researchers and teachers very often report on technical shortfalls of testing used in accountability. Several of them: deep cognition is missing, tests do not reflect the real state of teaching and learning, they ignore findings of research of learning and transfer of knowledge, tests do not reflect application of the learners' knowledge, and it leads to misinterpretations, etc (Donovan, Bransford, \& Pellegrino, 1999). The evident disconnection between test-design, their practice, and learning research is no small thing. It means that tests may not actually be measuring the learning for which schools are responsible. Nevertheless, "we act as if tests were valid, in the face of weak or limited evidence, making heavy and far-reaching decisions about schools, teachers, and learners while tests have low validity and limited meaning in accountability interpretations" (Baker, 2007).

One more observation - tests exert power. On the one hand, research shows that tests improve the learning of what is tested (Roediger \& Karpicke, 2006). On the other hand, testing results are often linked to sanctions; teaching therefore moves to conform to the content of tests - it is safer to practice test-like items in the classrooms, and this effect can be called "score inflation", when "institutional test anxiety uses up all the instructional oxygen in the classroom". This sort of "accountabalism" (a parallel to cannibalism, when testing becomes a value in itself and consumes much energy and time) does not improve the system of accountability itself (as Baker quotes Weinberger), neither it supplies teachers with valid data (Baker, 2007, 310).

These conclusions call for deep investigation of learning and teaching as well as the learners' development so that teachers can add valid data and fill in the blanks which remain after testing. Teachers' research becomes even more important because of the innovative character of modern teaching and learning and accent on the learners' individual development.

The practices of testing need wider and deeper investigation. Even a short insight allows us to make some conclusions - let us look at the results of the international tests launched 
by The Organization for Economic Co-operation and Development and the Programme for International Student Assessment, which include cross-curricula content, examine application of cognitive skills up to the ability of problem solving (OECD, 2007). The figures, which reflect the results and are organised in tables, show a great variety of performance between the highest and the lowest achievements in different countries. Latvia is somewhere in the middle. Certainly, some questions appear. If the collected figures reflect the reality objectively, do not the teachers in the countries with poor results teach their learners how to acquire knowledge, be creative or innovative? Do not they have opportunities to develop their individual potentials? These questions again call for more research as an everyday practice of teachers in every country to find weak points in teaching and learning or within multiple dynamic links during classes. This would be research in education.

The variety of OECD figures reflects the variety of schooling practices in the particular cultural settings of countries. This also creates a demand for a comparative research to investigate cultural peculiarities, their influence on the content, strategies, organizational settings, teacher education, as well as exchange of experiences and critical borrowing of technologies from each other. We also need investigations of educational policies, economics, or sociology - research about education - to explore a large variety of environmental factors.

When visiting the websites of the ministries of education, say, in neighbouring Norway and Finland or Lithuania and Estonia as well as remote countries where comparatively high results are reported, as Hong Kong or New Zealand, we will notice a great variety in the content, examination practices, accountability, teacher tertiary and further education, etc. First of all, what might seem striking is the great variety of options which are offered to the learners and which refers not only to the content and teaching but, what is most attractive, also to the examination practices with wide range of subject options (especially in New Zealand). Options for secondary level learners in different countries might remind us well-known placement or advanced placement examinations, even internationally recognised baccalaureate courses and examinations, as well as a wide range of courses or subjects to meet the learners' individual needs and interests.

Teachers in Latvia know that in the early 90-ties of the previous century, poorly prepared subject options for final examinations were introduced as an innovation in schools (and their outcomes). These changes left outside the culture- and tradition-based experiences of schooling in this country. All this lead to unpredicted consequences - many of school leavers applied for programmes which they could join, not because of their interests and future plans. Instead of their desires to meet their objectives, they had to find institutions of tertiary education where the entrance examinations where the same as their final examinations. This was an outcome that demonstrated non-research-based changes, when the main criteria for entrance became the wrong choice of final examinations, and the option offered to learners, in turn, became destructive.

Changes in European countries, especially in the enlarged EU, such as the Baltic countries, helped launch many initiatives in schooling without deep investigation. Therefore, change has become a constant phenomenon at schools while investigation of its reasoning, the real improvement, impact on the learners' achievements is being left behind considerably. Teachers have to include research into their everyday practice to minimize the harm which often accompanies changes in schooling. Certainly, they expect assistance from the universities: simple and sound methods of investigation, interpretation of the OECD and other data with the help of deep culture-based theoretical statements to guide practices, preparation of teachers for investigations in their everyday job to balance testing, etc, in other words, making research about education serve for creating targeted multiple dynamic links of classes. 


\section{Paradigm changes and new pedagogical orientations - a strong reason for investigation}

Educational research has made a substantial progress due to the investigations in psychology, educational psychology, and pedagogy in the 80 -ties and 90 -ties of the $20^{\text {th }}$ century. Elaborated theories of learning triggered a considerable change in accents - research and practices in pedagogy have moved from teachers' instruction to learners' activity, and this change has reached a good understanding of what highly professional pedagogical performance is. This is the area of conceptual changes, and the official documents of the countries as well as theoretical publications and technological issues reflect those changes. It makes a good background for each teacher to bring innovations to his/her everyday activities while in practice, the situations might be quite opposite: alongside with real paradigm change in schools we can see teachers who are not able to change their practice and even do not know why it is necessary. A deep concern that subject teachers are doing well without innovations is not a seldom fact.

Only adequate and complex research can reveal the peculiarities and impacts of appearing new approaches and systems in a complicated setting, which is made of paradigm changes, teachers' beliefs, their everyday practices, and their learners' achievements. Teachers' constantly practiced investigation can create a sound background for further developments of schooling and teacher education in our changing world.

The scientific revolution that started 300 years ago has accelerated enormously, but it will not stop at the beginning of the new post-modernism era - more things will change in more places in the next 10 years than in the previous 100 (F. Zakaria, 2006, as quoted by Baker, $2007,313)$. If our education stays trapped between traditional schooling, formal testing, etc, on the one hand, and constantly changing learners' needs on the other hand, the existing school system will be of no use for the learners' development. What is the outcome then? We can observe that the learners' achievements in schooling are only to some extent adequate to the needs that the school leavers experience when meeting the reality.

Another object of investigation appears - how to make schooling (content, teaching strategies, etc) of today's teaching and learning valid for the learners' life after school and their life-long learning.

Investigations of this problem have started long ago, and some suggestions and models have been produced within different cultures and pedagogical concepts: Glaser (1977), Klafki (1989, 1990), Baker (2007), The White Book by the European Commission (1997), etc.

There are topical and reasonable suggestions for teachers and teacher education, (see Tuning Project), tools for quality assurance of education for democratic citizenship in schools, etc issues which due to its system-making power are weaving and integrating school subjects and putting schooling into a new system (Birzea et al., 2005). Implementation of these valuable models also needs research-based changes in schools and teacher education.

To summarise, these and other similar findings would include the following learners' and, certainly, teachers' abilities to meet the challenges of a rapidly changing social situation and help teachers get out of the trap of instruction-based teaching and learning:

- rich knowledge base, adaptive knowledge, acquired learning strategies;

- pedagogical reasoning of using ICT, electronic games, etc as a reality, which makes a certain field of the learners' activities with or without schools' guidance - all of this kind that is being constantly used by learners - to put it all into pedagogical settings for serving the learners' development and achievements;

- creating assignments and options for the learners so that they have to use books and need reading alongside with "surfing" on the Internet; 
- transference of knowledge and abilities in and for a complex problem solving, leading to integrated knowledge and strategic thinking;

- meaningful learning, thus meaningful for the learners' educational tasks in every school subject, learning that is deeply rooted in the learners needs and perspectives;

- strategies of teaching leading towards powerful learning, targeted development of the learners' thinking to exclude the fractioned character of teaching-learning and curricula, which are split into different, separately existing subjects;

- constant development of self-regulated, self-managed learning by using balanced individual and partnership learning strategies;

- experiential learning, using life itself and the environment as a textbook and in addition to the textbooks;

- usage of virtual or real settings to acquire different social roles, competent and flexible performance, communication skills, and individuals' culture for life in a changeable environment;

- development of the learners' passion in at least one area on the background of integrated knowledge, practical skills, and learning strategies;

- research-based schooling and integrated examinations to promote a new-quality powerful learning, to measure integrated goals, learning experiences, ability of knowledge and skill transference, where tests constitute only a small part of assessment to reflect the learners' achievements, accomplishments, and school accountability;

- learners' choice should lead to a range of personal goals which are integrated with the goals envisaged by the standards and which put the standard goals into a set of the learners' personal needs as attractive and valuable schooling.

These orientations create a lot of large and small hypotheses to be tested, formulate criteria of transition into a learners' learning-centred process; they should initiate teachers' analytical thinking and researchers' abilities to evaluate and improve textbooks, teaching strategies, and curricula, as well as the learners' achievements in a guided pedagogical process. Teachers' research will address a question: what teachers think their learners need and what the learners think they need, as well as to what extent and how standards reflect the learners' needs and their implementation in teachers' everyday work. It might happen that the first question will initiate more questions to be answered by teachers: how the shift from instruction to learning, from standards to personally significant and meaningful goals, from textbooks to life, from teaching to education should be conducted, how it should take place and how it does take place (if at all) in our everyday practices.

There is one more reason for teachers' research. In a post-modern society, understanding of the very nature of the social phenomena becomes of great importance for pedagogy, especially in the era of dominating natural sciences and their influence (still strong!) on educational research. It is a matter of serious scientific investigations and it belongs to "the field of big researches". Teachers investigate social reality to improve their pedagogy and provide the learners with better opportunities to meet their individual needs for development. It is important and sufficient to know that pedagogy as a social reality is only to a certain extent related to nature while it crucially relates to psychology and social sciences. Therefore, teachers' investigations will use the conception of relationship between human beings and their environment as a background. Since the human being is both subject and object of this relationship, consequently, his/her achievements and development are in the centre of investigation, the concept of a human being itself and his/her development obtains crucial importance.

The above mentioned research in the 80-ies and 90-ties has shifted the accent from a human being's mechanical response to the environment towards an individual's initiated actions as 
a background of his/her development. This concept leads to the understanding that learning is already a process of the learner's development. Therefore, classes should perform multiple instructional dynamics to provide the best possible opportunities for the learners' selfconducted learning, intellectual, emotional, and social development. In the rapidly changing social environment, pedagogy again becomes a serious object of investigation.

Several questions arise from these statements in the context of a learner's learning-centred process:

- How far are learners products of nature (objects of natural sciences - defined by the regularities of these sciences, conclusions are used in educational research) and what is their social essence (objects of social sciences), their individual culture, which appears in their activities and communication and which develops in a pedagogically organized setting (learners' achievements and development - an object of educational research)? Why does in some cultural settings schooling lead to considerable achievements of the learners and why does in other settings and countries it show evidence of poor achievements?

- Is social reality, also schooling, external to individuals or is it the product of individual cognition and consciousness created by an individual's mind - a way how an individual perceives, evaluates schooling according to personally important criteria, makes personally valid decisions? What is more important for the learners' achievements - the objective reality or the way the learners perceive and evaluate it (also school, teachers, the way they function etc)?

- What is the very basis of good knowledge, how the learners acquire it in a guided process? What pedagogy should be chosen - how (painlessly for the learners' development) to change pedagogical process from instructional to learners' selfdirected learning?

These and similar questions cannot be adequately answered without investigation.

The answers include the following: teachers will respect physiology and anatomy, sociopolitical reality, which they cannot change, as well as the objective reality which is reflected in human beings' knowledge - these are objects of other than educational sciences and teachers will use regularities and conclusions discovered by scientists. The main field of teachers' research will be their learners' physical, emotional, intellectual, and social achievements in a pedagogical setting, communication and cooperation in schools and communities, improvement of pedagogy for the benefit of the learners. Every day teachers meet a lot of problems and under-investigated objects and phenomena, which interfere with their learners' development, their becoming cultured individuals in a cultural society.

Research and practices in pedagogy have moved from teachers' instruction to learners' activity, pedagogical targets are too complicated and individuals' development so varied and therefore demanding such a considerable teachers' flexibility that it is impossible to judge the learners' achievements by only testing them. Therefore, tests can prompt about some achievements while teachers need constant investigation to judge the individuals' development (which is the main goal of schooling) in the created multiple dynamic links within classes to interpret the reasons of the results of testing.

Actually, the speed of changes of the social processes does not leave space for long-lasting research programmes, piloting, improvement, and re-examination of the proposed models of teaching and learning. Of course, we need vast national or even international research programmes to investigate major tendencies. Targeted innovations and studies of concurrent validity of teaching and learning becomes an everyday activity, which accompanies constant improvement of pedagogy for the benefit of the learners. Teachers' professional qualification and teaching include a component called constant research; therefore, appropriate teacher 
education, tools, as well as time and financial support is needed to complete the development of this crucial competence.

\section{Research in education and about education}

It is important to understand the object of research in education to separate it clearly from research about education. Quite often masters' and even doctors' research represents a sort of mixture comprised of research in education on the one hand and phenomena of social environment - on the other hand. The latter is research about education or research with an educational perspective. Therefore, first we have to answer the question, what is the essence of a research in education?

To make it clear, we have to address Herbart's triangle modified with the mentioned intention. Education is targeted teachers' and hopefully, learners' activity to develop the learners' understanding, intellectual abilities, emotional culture, practical skills, learning skills, attitudes, etc. Teachers create multiple interactions between learners, learners and the teacher, learners and the subject matter. Interactions appear under the teachers' guidance or as the learners' initiative to make teaching and learning productive. By interactions we mean active processes of interpretation and mutual relations, which constitute teaching and learning. Teachers interpret and present subject matter to the learners. They interpret their learners while the latter interpret their teachers and the subject matter or the content and then respond or act accordingly. (Lampert, 2001). We can call these multiple interactions instructional dynamics (Ball \& Forzani, 2007, 530).

In learners' learning-centred process instructional dynamics (accent on teacher's activity) should be changed to multiple dynamic links which include communication, learners' initiative in cooperation, technologies, and other, for non-stop learning during the classes (from surface to deep and further to strategic learning).

Modified Herbart's triangle: constant regularities and dynamic links

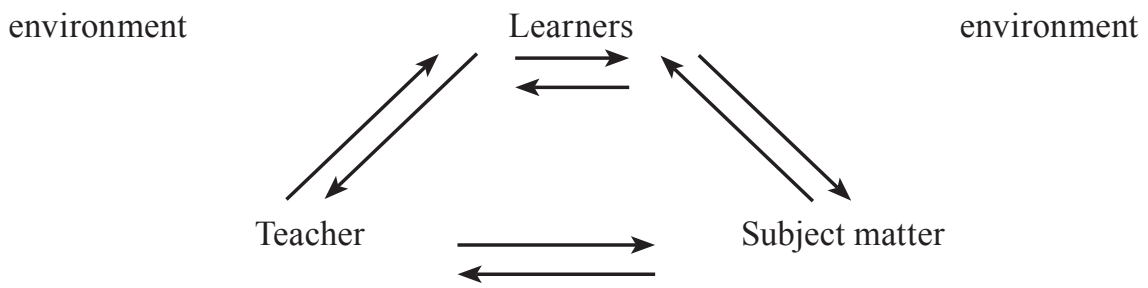

We have to distinguish between two levels of interactions.

1. Constant regularities common for any level of organized institutional education (Žogla, 1997, 8-9):

- learner-targeted, personally important, motivated activity;

- teachers' assistance, guidance, organizing function;

- teachers' and learners' activities directed towards the subject matter;

- teachers' and learners' mutual relations which are based on interaction;

- any influences from outside teaching-learning (reflected in the triangle) enter teachinglearning only if they are brought to classes by teachers, learners, or the subject matter.

Therefore, organized group education is based on cooperation, it needs teachers' activities to help their learners understand and accept the objectives of lessons or other forms of learning and teaching. It leads (or not) to valid, useful learners' achievements, or it might 
also lead to formal memorization and poor applicability of knowledge - the results depend on the character of the multiple dynamic links.

Teachers might hold deep knowledge in psychology (knowledge about the learners' development), also deep or even strategic knowledge in the branch of sciences which is represented by the subject matter; however, all this does not make him/her a good teacher because only integrated knowledge and skills can form his/her pedagogical professional knowledge and develop his/her pedagogical ability.

2. Multiple dynamic links, which occur during teaching and learning, constitute the changeable specific pedagogical system during the classes where many changeable interactions appear between teachers, learners, and the subject matter, and which lead to the learners' success:

- teachers shape the interactions, react to the learners' initiative, mood, and activities, initiate new ideas, etc;

- teachers use their learners' experience to help them develop their skills and abilities;

- teachers conduct the learners' attempts to create understanding of what they are going to or can achieve, help to create connections between their experience and the new ideas;

- teachers initiate learners' activities to engage with the content - compare, analyse, evaluate, verbalise their attitudes etc;

- teachers also modify the classroom environment to make it conductive to learning.

Therefore constant regularities (general, common to organised education) appear and are developed further through the multiple dynamic links (specific for each educational activity, they appear in communication, cooperation, structure of the subject matter, technologies, learners' attitudes) which, in turn, "feed" the constant regularities and by doing so develop a theory of pedagogy. Therefore, the object of educational research is multiple dynamic links that help formulate theoretical statements, which constitute the basis of education. This will be research in education, when we investigate every activity, the subject matter - every arrow in the triangle of the mutual relations and interactions which occur in classrooms and make education a reality.

Good knowledge of psychology is a background for understanding the learners' development and their needs. Good knowledge of a branch of sciences (say, mathematics) does not mean that a teacher can transfer it into the subject matter of mathematics without good knowledge of the learners' abilities and of possible multiple dynamic links during the classes. Teachers' multiple modifications can only make multiple dynamic links, which actually are pedagogy.

Teachers as well as researchers investigate the relations between social processes and schooling, such as parents' institutions, number of books in libraries, financial support, ethnic structure of the population etc. All these factors are in a way related to education and their investigation is important for their influence on education. Such research can give new information on the processes outside teaching and learning, and nevertheless it is research about education. They do not reveal multiple dynamic links inside education, do not reveal if teachers effectively conduct classes, as well as do not spot out the possible reasons of the learners' good or poor achievements. Therefore, researches about education belong to educational policy, educational philosophy, and educational sociology. Even sociology or ethnography of the learners' groups or teachers' activities during classes if investigated outside the context do not reveal the multiple dynamic links and therefore are considered as research about pedagogy or about education. 


\section{Good intentions do not guarantee...}

Good intentions do not guarantee good research (Hostetler, 2005, 17), similarly, the good intentions of teachers do not guarantee good teaching and educational results or good achievements of learners.

From article to article, from courses to courses, there are vigorously promoted, well- articulated slogans, such as "Leave no child behind", "All can learn and everyone should be taught appropriately", etc. Sounds familiar, but these slogans need an answer to a question articulated by Noddings (1992): "Learn what?" - do we understand "what" and "whom" in a liberal or an authoritarian, or a humanistic sense? Shall we continue being demanding towards a learner even if his/her abilities contradict with our demands, or shall we become liberal and reduce the demands? If we are too demanding, we face a failure in the individuals' achievements, if liberal, we have to think of certificates at the end of schooling - how far can we modify the curricula to remain within the premise of the enabling standards? This is also a reason for investigation.

Several considerations for the discussions on what a good investigation could be:

$\checkmark$ Researchers must be knowledgeable, well acquainted to the process of research, and responsible for the conclusions and decisions, which are based on the research. It means that teachers' as well as professional researchers' investigation must include the ethical component. Hostetler $(2005,17)$ invites us to acknowledge that research cannot be good without the researchers' deep understanding that what he/she does is really good and brings welfare to teachers and learners. Therefore, they have to know what they investigate and understand the way how they are serving the purpose (or not). To prove the importance of the ethical component in teachers' research, Hostetler $(2007,18)$ uses a situation common for schools: two children are fighting at the back of the classroom. A teacher should react by stepping in to stop the fight (quite a normative reaction) - a normal teachers' behaviour. A teacher researcher would do the same and put the situation into a context with other observations: is it a single case or regular, has it anything to do with human rights or a person's need to protect oneself, etc. The separation of teachers' roles from the roles of researchers' should not overdraw, and we characterise the shift from a normative educational process to a democratic one as "one within rather away from each other... Something vital is left out if we cannot embed the analysis within a realm of normative factors, such as a human being's desire for dignity and a fair chance at a good life." (Hostetler, 2007, 18) Analysis serves moral concerns and, even more, analysis itself should be a moral activity, a form of practical philosophy (Carr, 2003). There is a strong belief that teachers somewhat exaggerate the learners' rights; therefore, productive norms of being and doing together are being either lost or misunderstood. There is another strong belief that learners' human rights and teachers' human rights exist in a context, and never separately, to make it a background for the development of balanced experience between one's personal and others' rights, dignity, etc. This balance becomes possible only if we learn how to treat learners as human beings and only then as learners in their current social role. Consequently, we help our learners learn to perceive us as human beings and only on this background as teachers in our temporal social role.

$\diamond$ Research is a way to new knowledge, a kind of learning. If so, teachers should investigate (many of them do it successfully), organise a research-based teaching, and develop their and the learners' research strategies in the context of life-long learning. To do so, teachers undergo the main shift in teaching and learning - from normative, teacher- or subjectcentred pedagogy to dominating analytical and learners' learning-centred pedagogy. This also sounds as a nice slogan and will remain as such if we do not practice learning-domain pedagogy instead of teaching-domain pedagogy. 
$\diamond$ Teachers will agree that exaggerated learner-centred process might become non-pedagogical if we exclude the normative component out of it. In any organized process, norms of being and doing together do exist to make the process beneficiary for all and everyone. The problem is whether the learners can distinguish between norms which provide opportunities for everyone to achieve personally important goals and norms which violate a person's human rights. The balance between norms and freedom in a changeable world becomes an object of teachers' everyday observation and deep investigation. Constant observations can lead teachers to generalised conclusions on this balance - do everyday appearances in the learners' behaviour belong to single and random fact or are they habitual and thus demonstrate certain traits of the learners' personal features and culture? The observationbased articulation of the balance between norms set forth for productive functioning of a pedagogical process will lead to the learners' freedom and help teachers create a learners' learning-centred pedagogy.

$\diamond$ Understanding of this balance will lead to another balance - the one between the learners' and the teachers' human rights. Teachers' experience, which develops within a highly normative process, traps them and sometimes causes a feeling of lost illusions. We can articulate the traditional state of mutual relations by "learners should always obey their teacher". Otherwise, it goes outside the traditional frames, and teachers feel lost - they lack sound means to respond. A qualified teacher will extract some positive qualities out of each happening, and a professional pedagogue will use even undesirable facts as a reason for further educational activity - a learner's non-cultured behaviour, violated human rights, etc, will become a reason for discussions, self-evaluation, and evaluation. In other words, the learners' and the teacher's mutual relations in this rapidly changing world should become a matter of research-based education to discover a cultured way of cooperation and communication on the background of respect towards human rights. Thus, mutual relations become a good textbook for democratic citizenship education. Besides, several school system-making publications are now available (see All-European Study..., 2004; Birzea et al., 2005; Duerr, 2005; Gollob et al., 2005; Plan of Action..., 2006), and they, if used appropriately, will help teachers create targeted multiple dynamic links.

$\diamond$ Balance in mutual relations relates to another item of good research - responsibility of the researchers for the validity of the collected data and their interpretation, conclusions and suggestions or decisions made by teachers on the background of their research.

$\diamond$ A good research conducted by a teacher will be educational. For a while, imagine teachers evaluating the learners' achievements. We give them scores for their success (pay attention to the wording: they learn and we give them scores, and by doing so we exclude selfevaluation and development of the learners' experience of self-evaluation). For instance, we give scores in maths irrespective of the learners' particular backgrounds: experience, abilities, social situation in which he/she lives and belongs to, values he/she follows, etc. Traditionally teachers will give scores for maths as the standards denote it, while teachers researchers will investigate the reasons of good or bad learners' achievements to conduct appropriate and pedagogically valid assistance to the learners' self-conducted learning; they will modify the subject matter accordingly. Learners go to school because they do not know things they should know, they go to school to become able to use their knowledge and learn how to learn; therefore, professional teachers will not only answer to their learners' articulated needs but also initiate the development of their needs, which will become a motive of their self-development by acquiring the targets set forth by standards.

$\diamond \quad$ There is one more problem for discussion in the context of teachers' investigation. Professional researchers, educators, and doctoral students work out theoretically sound and practically tested pedagogical models. The models provide the learners with good opportunities to achieve in a certain educational area or a subject. Quite often these models function only 
when they are "in the hands" of the researcher, the author of the model. As soon as another teacher uses them, the results become vague, and teachers return to their usual practice. The reason is embedded in the research itself - the authors of the models practice research-based teaching and learning, and by doing so they reach deep or even strategic learning and deep understanding of the model's pedagogical value. A teacher's understanding conducts his/ her choice in the classroom - puts specific actions into a logical, learners' learning-oriented chain or multiple dynamic links which lead to the desired achievements or re-direct the learners' actions towards the desired achievements. Teachers have to adopt new models, identify their suitability for a certain setting before they use them.

$\diamond$ A new classroom culture based on several principles has started in the 90 -ies, and it can be adopted and developed in schooling on the background of teachers constant investigations:

- an atmosphere of individual responsibility of teachers and learners, communal sharing of moral values, and partnership;

- mutual respect between teachers/educators and learners, which will not enter the classroom just because we wish it to enter - classroom settings or multiple dynamic links should be created; their design, teacher-conducted learning, self-conducted learning, etc should lead to the manifestation of these values in our mutual relations;

- establishment of a community of discourse that facilitates constructive discussion, questioning, friendly criticism, etc - a full range of non-stop dialogues in the classrooms;

- usage of learners' information and knowledge obtained outside classrooms and programmes in the classroom, respect towards the learners wish to know more as well as their developed abilities in particular areas.

Research has several characteristics which distinguish it from every-day problem-solving in classrooms and observations. Teachers need the latter, and observation might be random, therefore insufficient for deep conclusions. To improve teaching-learning, research meets the following characteristics:

- it is targeted, systematic, planned, and controlled;

- research makes an important component of teachers' professional everyday activity, therefore teachers should be educated for it;

- research combines theoretical analysis and empirical investigation, looks for theoretical statements and background to check subjective observations and beliefs by the objective reality;

- research is a synthesis of teachers' professional education, experience and reasoning;

- it is self-correcting due to new knowledge on the object of investigation - the main reason and outcome not only of teachers' but also of every scientist's research.

\section{Research to know more}

In the context of teachers' research, it is worth to discuss research as a kind of learning and getting new knowledge in more detail. To start with, there is Gadamer's statement: "Only a person who has questions can have knowledge." The author continues: “...there is no such thing as a method of learning to ask questions, of learning to see what is questionable. On the contrary, the example of Socrates teaches that the important thing is the knowledge that one does not know." (Gadamer, 1989, 365) In other words, if we realise what we do not know, we start learning (with a teachers' assistance, self-directed - learn from textbooks, from observations in everyday life, or by a targeted investigation of a problem). 
Research can start with simple questions: what is this, how it develops or functions, how to better use it, etc. Even if there is no school for learning to ask questions, every lesson in a learners' learning-centred classroom is designed so that it initiates the learners' and the teachers' questions. A good practice of initiating questioning and keeping discussions hot in the classrooms is a matter of teachers' professionalism, and investigation of it might lead to a non-stop learning and put current teaching and learning into the context of life-long learning, or even more - it might transform everyday learning to a life-long affair. A good teaching and learning would open the learners' minds for new questions and new discussion, while the normative process might satisfy teachers by reaching an answer to close or stop questioning. (A learner gives an answer close to a textbook, and the teacher, being satisfied with the learners' reproduction, closes further questioning, thus closes further thinking.) The latter way leads to some knowledge of the learners, but it does not lead to learners' ability of seeking reasons for questioning and self-conducted learning.

Knowledge which learners, or, might be, also teachers do not know is a special case of teachers' investigation. I dare to suggest that knowledge which we do not know yet is the main content of teaching and learning - the reason why the learners go to school. It is here that we remember Vygotsky's “zone of proximal development”, and the main question for a teacher's research is: whether I locate my teaching into this zone for every individual, do I facilitate his/her emotional, intellectual, physical, and social development in the best possible way? In other words, do I create multiple dynamic links, which keep learning and teaching targeted and leads to the learners' success.

The suggestion might sound as ideal, but this is still the background understanding of learning as development and teaching as facilitating the learners self-conducted learning. It becomes even more important in the field of expanding information, where learners sometimes know more than the standards of a subject suggest and do not know simple things, which might appear to be basic for further learning. This imbalance should also become an object of teachers' research.

Teachers learn methods of educational research in the institutions of tertiary education, and programmes of teacher education do include possibilities to develop this experience. If the suggested scope and quality is not sufficient, it is easy to improve the situation. The state of mind imbeds this ability - a state of teachers' as researchers' mind.

Here I would suggest a discussion on creativity as a teacher's professional quality. Do teacher education programmes include enough possibilities for the students to be creative? The question leads not so much to the essence of creativity, but to the way how the educators conduct classes at the universities. I dare to conclude that students' creativity correlates to their reading - the amount, quality, and achievements of reading both professional literature and fiction. From time to time, the educators feel captured by the students' poor reading and limited scope of their mind and thinking, when practical activities and discussions become vague due to it. Development of thinking starts at our schools, and therefore teachers' and learners' reading and speech constitute a serious object of teachers' concern and research. Actually, success will come by the way how teachers present the assignment and whether reading is included there - it might happen that there is nothing to investigate as teachers simply skip reading exercises and therefore reading drops out of the multiple dynamic links in the classrooms.

A syndrome of over-flooding information and accessibility of mass media might be a reason for poor reading, and this fact itself is a reason for teachers' research. I should say, not so much the impact of media, which should be investigated (let us leave it for professional researchers), but the way we should conduct learning so that learning itself is attractive and reading, as well as thinking and learners' views, which are shared in the classrooms, become a personally important value. Teachers need new knowledge of good teaching in today's schools. I should invite teachers and educators to address the learners' needs, which they experience and which 
they should experience, to be compatible in this world. Classroom activities will be targeted if teachers find a way to meet such needs as being important and able to demonstrate one's achievements during the classes and in as many subjects as possible - a need for belonging and personal freedom, a need for identification and dignity, a need for being honest and being treated honestly. Thus, teachers present the subject matter of each class at school in a way that initiates learners' thinking.

The USA colleagues on the background of the lesson study (the USA context might initiate some ideas for other countries) suggest three types of research in order to make the still dominating instruction as a form of teaching and learning most effective, vigorously explore lessons' potential, use research as a tool for improvement and change the instruction-domain for the learning-domain:

- creation of a broader knowledge-base about the lesson study and its possibilities to develop sound ideas of the central features of lessons nowadays;

- explication of the lesson study's mechanisms;

- cycles of design-based research that test key design features and create "actionable artifacts" to leverage learning at new sites (Lewis et al., 2006, 10).

I would like to add one more - a research-based modification of the subject matter and pedagogical tools to make lessons conductive to meeting the learners' needs (those which our learners clearly articulate and those which must be developed, as the need to know more, the need to question, the need to discuss, the need to express and prove ones views, etc).

\section{Instead of conclusions}

From a humanistic perspective, a teacher as a human being demonstrates his/her behaviour in the classroom, protects their and their learners' rights, where other human beings (their learners) have come to develop their potentials in a humane setting. In this setting we, human beings, are in the temporal roles of a learner and teacher, therefore our mutual relations are based on common humane values and represented by pedagogical means. We conduct researchbased classes and investigate pedagogical means if they lead teachers and learners towards their personal freedom and competent performance.

It might be a specific, pedagogically non-conducted situation of a classroom, where normative thinking develops on the background of normative traditions, which violate personal rights and mutual relations. Investigation can help teachers understand the essence of a humanistic approach in pedagogy and its practices in creating multiple dynamic links during classes, which are conductive towards learning and respectful towards individualities.

A large amount of professional literature sometimes causes a negative effect - if it is so vast that one is not able to acquire it all, there is no use of even starting. Teachers' reading might also be a problem to investigate, especially the way how reading develops teachers' pedagogical thinking in creating a learners' learning-centred process.

The considerable workload of teachers sometimes stops them in their choice of a new way to improve organised classroom setting, even more, leads them away from perceiving investigation as a component of their professional competences and activities, makes them consider it as an additional duty which is neither paid for nor supported. Teachers need appropriate knowledge and simple tools for constant investigation in classrooms, they also need support in the development of their belief that research will make their job targeted and therefore less complicated; furthermore, that it can lead to better achievements.

All the above-mentioned is extremely important for good education; still, we have to distinguish between research in education and research about education to make teaching and learning a learners' learning-centred, thus an effective pedagogical affair. 


\section{References}

All-European Study on Education for Democratic Citizenship Policies. (2004) Council of Europe Publishing.

Ball, D. L., Forzani, F. M. (2007) Wallace Foundation Distinguished Lecture. What Makes Education Research "Educational"? Educational Researcher, Vol. 36, No. 9, pp. 529-540.

Baker, E. L. (2007) Presidential Address. The End(s) of Testing. Educational Researcher. An Official Journal of the American Educational Research Association. Vol. 36, No. 6, pp. 309-317.

Birzea, C., Cecchini, M., Harrison, C., Krek, J., \& Spajic-Vrka, V. (2005) Tool for Quality Assurance of Education for Democratic Citizenship in Schools. UNESCO, Council of Europe, Centre for Education Policy Studies.

Bruner, J. (1996) The Culture of Education. Cambridge, MA: Harvard University Press.

Carr, W. (2003) Educational Research and its Histories. In Sikes, P., Nixon, J., \& Carr, W. (Eds.) The Moral Foundation of Educational Research (pp. 6-17). UK: Open University Press.

Donovan, M. S., Bransford, J. D., \& Pellegrino, J. W. (Eds.) (1999) How People Learn: Bridging Research and Practice. Washington, DC: National Academy Press.

Duerr, K. (2005) The School: A democratic learning community. The All-European Study on Pupils' Participation in School. Council of Europe.

Gadamer, H.-G. (1989) Truth and Method. $2^{\text {nd }}$ ed. New-York: Continuum.

Gollob, R., Huddleston, E., Krapf, P., Salema, M.-H., \& Spajic-Vrka, V. (2005) Tool on Teacher Training for Education for Democratic Citizenship and Human Rights Education. Council of Europe.

Hostetler, K. (2005) What is "Good" Educational Research? Educational Researcher. An Official Journal of the American Educational Research Association. Vol. 34, No. 6, pp. 16-21.

Finland Ministry of Education (2007) The Finnish matriculation examination. Retrieved December 20, 2007, from http://www.ylioppilasturkinoto.fi/english. Retrieved in November, 2007.

Klafki, W. (1989) Die bildungstheoretische Didaktik im Ramen kritisch-konstruktiver Erziehungswissenschaft. In: Gudjons H., Teske R., \& Winkel R. (Hg.) S. 11-26.

Klafki, W. (1990) Abschied von der Aufklaerung? Grundzuege eines bildungtheoretischen Gegenentwurfs. In: Krueger H.-H. (Hg.) Abschied von der Aufklaerung? Opladen. S. 91-104.

Lampert, M. (2001) Teaching Problems and the Problems of Teaching. New Haven, CT: Yale University Press.

Lewis, K., Perry, R., \& Murata, A. (2006) How Should Research Contribute to Instructional Improvement? The Case of Lesson Study. Educational Researcher. Vol. 35, No. 3, pp. 3-14.

New Zealand Ministry of Education (2007) Schools. Retrieved December 20, 2007, from http://www. minedu.govt.nz. Retrieved in October, 2007.

Organization for Economic Co-operation and Development. (2007) Programme for International Student Assessment. Retrieved December 21, 2007, from http://www.oecd.org/topic/en. Retrieved in October, 2007.

Plan of Action. World Programme for Human Rights Education. (2006) New-York, Geneva: United Nations, UNESCO, Office of the United Nations High Commissioner for Human Rights.

Roediger, H. L., \& Karpicke, J. D. (2006) Test-enhanced Learning: Taking Memory Tests Improves Long-term Retention. Psychological Science. Vol. 17, No. 3, pp. 249-255.

Teaching and Learning - Towards the Learning Society. (1996) Luxemburg: Office for Official Publications of the European Communities. (The White Book of the European Commission.)

Tuning Project: http://tuning.unideusto.org/tuningeu/. Retrieved in December, 2007.

Žogla, I. (1997) Skolas pedagogija. Skolotājs. Nr. 5, 1997, 8-10. 


\section{Kopsavilkums}

Izmaiṇas izglîtî̉ā un pedagoǵijā kopš pagājušā gadsimta astoṇdesmitajiem un deviṇdesmitajiem gadiem ieviesa skolās inovācijas, kuras vēl joprojām maina pedagoǵisko procesu un skolotāju izglītîbu. Daudz ideju un risinājumu ir aizgūts no citām valstīm un kultūrām, pieņemot tos kā ievērojamu uzlabojumu skolu darbā, daudzi risinājumi ienāca izglītības sistēmās bez pilnvērtīgas izpētes un modificēšanas atbilstoši pedagoǵiskajām tradīcijām un kultūrkontekstam.

Dažas aktualitātes, kuras attiecas uz pedagoǵiskajiem pētījumiem un izpēti kā skolotāju kompetences un darbības nozīmīgu komponentu, ir aplūkotas šajā rakstā: testēšanas problēmas, to nepietiekamā saikne ar mācību procesu, testu pārvēršanās par pašmērķi un spēcīgu kontroles formu - šīs un citas problēmas aicina skolotājus pētīt pedagoǵisko procesu, tā efektivitāti, skolēnu sasniegumus organizētā pedagoǵiskā vidē.

Plašu nacionālo pētījumu un konkrētu pedagoǵisko parādību izpēte kā skolotāja darbības komponents ir aplūkots, piedāvājot diskusijai vairākas domas par to, kas varētu būt produktīvs skolotāja pētījums ikdienā un kas epizodisku novērošanu šķir no pētījuma, lai pamatotu pedagoǵiski korektu lēmumu par labu skolēna attīstībai.

Daudzi pētījumi ir veltīti pedagoǵijai, tomēr pētnieka kḷūdas izpētes priekšmeta izvēlē izpaužas neprecīzos secinājumos un ieteikumos. Tādēl raksts aptver ievadu divu jēdzienu izpratnē, proti, pētījumi pedagogijjā un pétījumi par pedagogiju jeb ar izglītības iegūšanu saistīti pētījumi, kas palīdzēs pētniekiem korekti izmantot testus.

Mūsdienās plaši izmantojamie testi iegūst pārsvaru pedagoǵiskajā procesā, tādēḷ tie nevar būt produktīvi izmantojami bez padziḷinātiem pētījumiem, lai pārveidotu mācības no mācīšanas kā galvenās darbības uz mācīšanos - ne tikai skolēna, bet arī skolotāja mācīšanos, kas kḷūst iespējama pētnieciskā mācību procesā.

Atslēgvārdi: pētniecība kā skolotāja profesionalitātes komponents, pedagogisko pētījumu priekšmets.

\section{The author}

Irēna Žogla - Dr. habil. Paed., Professor of the University of Latvia.

Research profiles - theories of teaching and learning, teacher education.

E-mail: irena.zogla@lu.lv 



\section{LIST OF PARTICIPANTS}

$\longrightarrow$ 


\begin{tabular}{|c|c|c|c|c|}
\hline 1. & Līga Āboltiņa & University of Latvia & Latvia & ligaa@lu.lv \\
\hline 2. & $\begin{array}{l}\text { Britta Alin } \\
\text { Åkerman }\end{array}$ & $\begin{array}{l}\text { Stockholm Institute of Education } \\
\text { and Karolinska Institutet }\end{array}$ & Sweden & Britta.Alin-Akerman@ki.se \\
\hline 3. & $\begin{array}{l}\text { Daiva } \\
\text { Alifanoviene }\end{array}$ & Šiauliai University & Lithuania & \\
\hline 4. & $\begin{array}{l}\text { Stefanija } \\
\text { Alisauskiene }\end{array}$ & Šiauliai University & Lithuania & stefa@su.lt \\
\hline 5. & $\begin{array}{l}\text { Algirdas } \\
\text { Ališauskas }\end{array}$ & Šiauliai University, & Lithuania & \\
\hline 6. & $\begin{array}{l}\text { Jonas } \\
\text { Ambrukaitis }\end{array}$ & Šiauliai University & Lithuania & \\
\hline 7. & Rudīte Andersone & University of Latvia & Latvia & rudite.andersone@lu.lv \\
\hline 8. & Zenta Anspoka & $\begin{array}{l}\text { Riga Teacher Training and } \\
\text { Educational management } \\
\text { academy }\end{array}$ & Latvia & zenta.anspoka@rpiva.lv \\
\hline 9. & Dagmāra Ausekle & University of Latvia & Latvia & dagmara.ausekle@lu.lv \\
\hline 10. & Anita Auziņa & University of Latvia & Latvia & anita.auzina@lu.lv \\
\hline 11. & Austra Avotinga & University of Latvia & Latvia & aavot@lanet.lv \\
\hline 12. & $\begin{array}{l}\text { Svetlana } \\
\text { Baigozina }\end{array}$ & A/S Datorzinibu centrs & Latvia & Svetlana.Baigozina@dzc.lv \\
\hline 13. & $\begin{array}{l}\text { Reda } \\
\text { Baranauskienè }\end{array}$ & Šiauliai University & Lithuania & afk@hu.su.lt \\
\hline 14. & $\begin{array}{l}\text { Ingrida } \\
\text { Baranauskienè }\end{array}$ & Šiauliai University & Lithuania & i.baranauskiene@cr.su.lt \\
\hline 15. & Sanita Baranova & University of Latvia & Latvia & sanita.baranova@lu.lv \\
\hline 16. & Rasa Barauskiene & Vilnius pedagogical university & Lithuania & \\
\hline 17. & $\begin{array}{l}\text { Marija } \\
\text { Barkauskaite }\end{array}$ & $\begin{array}{l}\text { Department of Education Science } \\
\text { Pedagogical University }\end{array}$ & Lithuania & edukologija@vpu.lt \\
\hline 18. & Andris Bērziņšs & $\begin{array}{l}\text { Rīgas Būvamatniecības } \\
\text { vidusskola }\end{array}$ & Latvia & andrisberzins7@inbox.lv \\
\hline 19. & Dina Bethere & Liepaja Academy of Pedagogy & Latvia & dina@lieppa.lv \\
\hline 20. & Rita Birziņa & University of Latvia & Latvia & rita.birzina@lu.lv \\
\hline 21. & Helena Björk & $\begin{array}{l}\text { The National Centre for Suicide } \\
\text { Research and Prevention of } \\
\text { Mental Ill-Health }\end{array}$ & Sweden & \\
\hline 22. & Mike Blamires & $\begin{array}{l}\text { Canterbury Christ Church } \\
\text { University }\end{array}$ & & M.Blamires@canterbury.ac.uk \\
\hline 23. & Dainuvīte Blūma & University of Latvia & Latvia & dainuvite.bluma@lu.lv \\
\hline 24. & $\begin{array}{l}\text { Tamāra } \\
\text { Bogdanova }\end{array}$ & $\begin{array}{l}\text { Riga Teacher Training and } \\
\text { Educational management } \\
\text { academy }\end{array}$ & Latvia & tamara_bog@one.lv \\
\hline 25. & Ilze Brante & $\begin{array}{l}\text { University of Latvia, Ministry of } \\
\text { Education and Science }\end{array}$ & Latvia & Ilze.Brante@izmpia.gov.lv \\
\hline 26. & Ilze Briška & $\begin{array}{l}\text { Riga Teacher Training and } \\
\text { Educational management } \\
\text { academy }\end{array}$ & Latvia & ilze.briska@rpiva.lv \\
\hline 27. & Dagnija Cēdere & University of Latvia & Latvia & dagnija.cedere@lu.lv \\
\hline 28. & Mihail Chehlov & University of Latvia & Latvia & \\
\hline 29. & Liliana Ciascai & $\begin{array}{l}\text { Babes-Bolyai University, Cluj- } \\
\text { Napoca }\end{array}$ & Romania & liliciascai@yahoo.com \\
\hline 30. & Emīlija Černova & University of Latvia & Latvia & emilija.cernova@lu.lv \\
\hline 31. & Anna Dahlberg & $\begin{array}{l}\text { The National Centre for Suicide } \\
\text { Research and Prevention of } \\
\text { Mental Ill-Health }\end{array}$ & Sweden & \\
\hline 32. & Linda Daniela & University of Latvia & Latvia & 1dani@lanet.lv \\
\hline 33. & Jelena Davidova & Daugavpils University & Latvia & jelena.davidova@du.lv \\
\hline
\end{tabular}




\begin{tabular}{|c|c|c|c|c|}
\hline 34. & Marc Depaepe & K.U. Leuven, Campus Kortrijk & & \\
\hline 35. & Māra Dirba & University of Latvia & Latvia & dirbamara@inbox.lv \\
\hline 36. & $\begin{array}{l}\text { Irina } \\
\text { Direktorenko }\end{array}$ & $\begin{array}{l}\text { Riga Teacher Training and } \\
\text { Educational management } \\
\text { academy }\end{array}$ & Latvia & direktorenko@inbox.lv \\
\hline 37. & Anita Eiholca & University of Latvia & Latvia & \\
\hline 38. & $\begin{array}{l}\text { Auksė } \\
\text { Endriulaitienè }\end{array}$ & $\begin{array}{l}\text { Vytautas Magnus University, } \\
\text { Kaunas }\end{array}$ & Lithuania & \\
\hline 39. & Andra Fernāte & University of Latvia & Latvia & fernate@lanet.lv \\
\hline 40. & Irina Filipova & Zolitude Grammar School & Latvia & psirin@mail.ru \\
\hline 41. & Ilze Freimane & & Latvia & \\
\hline 42. & Beatrise Garjāne & University of Latvia & Latvia & \\
\hline 43. & Janis Gedrovics & $\begin{array}{l}\text { Riga Teacher Training and } \\
\text { Educational management } \\
\text { academy }\end{array}$ & Latvia & janis.gedrovics@rpiva.lv \\
\hline 44. & Laima Geikina & University of Latvia & Latvia & \\
\hline 45. & Jūratė Gelžinienè & Klaipèda University & Lithuania & juragel@gmail.com \\
\hline 46. & $\begin{array}{l}\text { Vitolda Sofija } \\
\text { Glebuviené }\end{array}$ & Vilnius Pedagogical University & Lithuania & lijola@centras.lt \\
\hline 47. & Imants Gorbans & University of Latvia & Latvia & imants.gorbans@lu.lv \\
\hline 48. & $\begin{array}{l}\text { Auksė } \\
\text { Grudžinskytė }\end{array}$ & Klaipèda University & Lithuania & agrudzinskyte@yahoo.com \\
\hline 49. & $\begin{array}{l}\text { Dzintra } \\
\text { Grundmane }\end{array}$ & University of Latvia & Latvia & dzintrag@lu.lv \\
\hline 50. & Thomas Hofsäss & Universität Leipzig & Germany & hofsaess@rz.uni-leipzig.de \\
\hline 51. & Aldona Homicha & Latvian Police academy & Latvia & aldonah@inbox.lv \\
\hline 52. & Rutger Ingelman & Stockholm University & Sweden & Rutger.ingelman@did.su.se \\
\hline 53. & Inese Jurgena & University of Daugavpils & Latvia & inese.jurgena@rpiva.lv \\
\hline 54. & $\begin{array}{l}\text { Elizabete } \\
\text { Kadakovska }\end{array}$ & University of Latvia & Latvia & elizabetek@yahoo.com \\
\hline 55. & $\begin{array}{l}\text { Daiga Kalēja- } \\
\text { Gasparoviča }\end{array}$ & $\begin{array}{l}\text { Riga Teacher Training and } \\
\text { Educational management } \\
\text { academy }\end{array}$ & Latvia & dakaga@inbox.lv \\
\hline 56. & Daiga Kalniņa & University of Latvia & Latvia & daiga.kalnina@lu.lv \\
\hline 57. & Aija Kalve & $\begin{array}{l}\text { Riga Teacher Training and } \\
\text { education of menagament } \\
\text { academy }\end{array}$ & Latvia & aija.kalve@way.lv \\
\hline 58. & Irena Kapustienè & Vilnius Pedagogical University & Lithuania & 1ijola@centras.lt \\
\hline 59. & Ārija Karpova & University of Latvia & Latvia & \\
\hline 60. & Irina Kazuša & Riga Stradins University & Latvia & edwins@btv.lv \\
\hline 61. & Albina Kepalaitė & $\begin{array}{l}\text { Vytautas Magnus University, } \\
\text { Kaunas }\end{array}$ & Lithuania & a.kepalaite@smf.vdu.lt \\
\hline 62. & Iveta Kestere & University of Latvia & Latvia & fa626815@skynet.be \\
\hline 63. & Dalia Kiliuvienè & Klaipèda University & Lithuania & education.res@gmail.com \\
\hline 64. & $\begin{array}{l}\text { Vladimirs } \\
\text { Kincāns }\end{array}$ & University of Latvia & Latvia & Vladimirs.Kincans@lu.lv \\
\hline 65. & $\begin{array}{l}\text { Rasa Monika } \\
\text { Knyza }\end{array}$ & $\begin{array}{l}\text { Vytautas Magnus University, } \\
\text { Kaunas }\end{array}$ & Lithuania & rasaknyza@yahoo.com \\
\hline 66. & Maija Kokare & University of Latvia & Latvia & maija.kokare@patnis.lv \\
\hline 67. & Tatjana Kokina & Daugavpils medicīnas koledža & Latvia & \\
\hline 68. & Asta Kraujeliene & Vilnius pedagogical university & Lithuania & \\
\hline
\end{tabular}




\begin{tabular}{|c|c|c|c|c|}
\hline 69. & $\begin{array}{l}\text { Linutė } \\
\text { Kraujutaitytè }\end{array}$ & Mykolas Romeris University & Lithuania & juskevic9@yahoo.com \\
\hline 70. & $\begin{array}{l}\text { Laimrota } \\
\text { Kriumane }\end{array}$ & $\begin{array}{l}\text { Riga Teacher Training and } \\
\text { Educational management } \\
\text { academy }\end{array}$ & Latvia & laimrota.kriumane@rpiva.lv \\
\hline 71. & Ata Krūmiņa & $\begin{array}{l}\text { Pedagoğiskais centrs } \\
\text { "Eksperiments }\end{array}$ & Latvia & \\
\hline 72. & $\begin{array}{l}\text { Irena } \\
\text { Krustozolina }\end{array}$ & $\begin{array}{l}\text { Riga Teacher Training and } \\
\text { Educational management } \\
\text { academy }\end{array}$ & Latvia & irena.krustozolina@rpiva.lv \\
\hline 73. & Aīda Krūze & University of Latvia & Latvia & aida.kruze@lu.lv \\
\hline 74. & Anna Kūkoja & Zuyd University & Netherlands & \\
\hline 75. & Tatjana Kurilova & University of Latvia & Latvia & \\
\hline 76. & $\begin{array}{l}\text { Oksana } \\
\text { Kuzmenko }\end{array}$ & University of Latvia & Latvia & \\
\hline 77. & Elen Laanemaa & Estonian Public Service Academy & Estonia & kinks73@hot.ee \\
\hline 78. & Ilona Laizāne & University of Latvia & Latvia & \\
\hline 79. & Viesturs Lāriņš & $\begin{array}{l}\text { Latvian Academy of Sport } \\
\text { Education }\end{array}$ & Latvija & \\
\hline 80. & Aivars Lasmanis & University of Latvia & Latvia & aivars.lasmanis@lu.lv \\
\hline 81. & $\begin{array}{l}\text { Aleksandra } \\
\text { Latunina }\end{array}$ & University of Latvia & Latvia & mm21032@lu.lv \\
\hline 82. & Cathy Lawrence & $\begin{array}{l}\text { Canterbury Christ Church } \\
\text { University }\end{array}$ & UK & $\begin{array}{l}\text { Cathy.lawrence@canterbury. } \\
\text { ac.uk }\end{array}$ \\
\hline 83. & Anita Līdaka & Liepaja Academy of Pedagogy & Latvia & anitalidaka@inbox.lv \\
\hline 84. & Aiva Līduma & University of Latvia & Latvia & \\
\hline 85. & Diana Liepa & University of Latvia & Latvia & diana5511@inbox.lv \\
\hline 86. & Justina Liesienè & $\begin{array}{l}\text { Vytautas Magnus University, } \\
\text { Kaunas }\end{array}$ & Lithuania & J.Liesiene@smf.vdu.lt \\
\hline 87. & Šarūnas Litvinas & Klaipėda University & Lithuania & sarunaslit@gmail.com \\
\hline 88. & Maja Ljubetić & University of Split & Croatia & ljubetic@ffst.hr \\
\hline 89. & Ineta Lūka & $\begin{array}{l}\text { School of Business } \\
\text { Administration Turiba }\end{array}$ & Latvia & ineta@turiba.lv \\
\hline 90. & Larisa Mal̦kova & University of Latvia & Latvia & larisa@ultranet.lv \\
\hline 91. & Iuliana Marchis & $\begin{array}{l}\text { Babes-Bolyai University, Cluj- } \\
\text { Napoca }\end{array}$ & Romania & marchis_juliana@yahoo.com \\
\hline 92. & $\begin{array}{l}\text { Marina } \\
\text { Marčenoka }\end{array}$ & $\begin{array}{l}\text { Rēzeknes augstskolas Personības } \\
\text { socializācijas pētîjumu institūts }\end{array}$ & Latvia & \\
\hline 93. & Māra Marnauza & $\begin{array}{l}\text { Riga Teacher Training and } \\
\text { Educational management } \\
\text { academy }\end{array}$ & Latvia & mara.marnauza@choir.lv \\
\hline 94. & Irīna Maslo & University of Latvia & Latvia & irina.maslo@lu.lv \\
\hline 95. & Jānis Mencis & University of Latvia & Latvia & mencis@lanet.lv \\
\hline 96. & Talivaldis Mezhis & $\begin{array}{l}\text { Riga City Council Education, } \\
\text { Youth and Sports Department }\end{array}$ & Latvia & Taivaldis.Mezis@riga.lv \\
\hline 97. & \begin{tabular}{|l|} 
Tatyana \\
Minakova
\end{tabular} & Daugavpils University & Latvia & tatjanaart@rambler.ru \\
\hline 98. & $\begin{array}{l}\text { Ona } \\
\text { Monkeviciene }\end{array}$ & Vilnius pedagogical university & Lithuania & ona.monkeviciene@vpu.lt \\
\hline 99. & Sigita Montvilaite & Vilnius pedagogical university & Lithuania & smontvilaite@yahoo.com \\
\hline 100. & Daina Možeika & University of Latvia & Latvia & tuttii@inbox.lv \\
\hline 101. & Ināra Muraško & $\begin{array}{l}\text { Riga Teacher Training and } \\
\text { Educational management } \\
\text { academy }\end{array}$ & Latvia & \\
\hline
\end{tabular}




\begin{tabular}{|c|c|c|c|c|}
\hline 102. & Ivars Muzis & $\begin{array}{l}\text { Riga Teacher Training and } \\
\text { Educational Management } \\
\text { academy }\end{array}$ & Latvia & muzisivars@inbox.lv \\
\hline 103. & Dita Nīmante & University of Latvia & Latvia & ditas@latnet.lv \\
\hline 104. & Attila Nóbik & University of Szeged & Hungary & nobikattila@gmail.com \\
\hline 105. & Inga Odiņa & $\begin{array}{l}\text { Sarkanā Krusta medicīnas } \\
\text { koledža }\end{array}$ & Latvia & \\
\hline 106. & $\begin{array}{l}\text { Karine } \\
\text { Oganisjana }\end{array}$ & University of Latvia & Latvia & karine.oganisjana@apollo.lv \\
\hline 107. & Adrian Opre & $\begin{array}{l}\text { Babes-Bolyai University, Cluj- } \\
\text { Napoca }\end{array}$ & Romania & adrianopre@psychology.ro \\
\hline 108. & Dana Opre & $\begin{array}{l}\text { Babes-Bolyai University, Cluj- } \\
\text { Napoca }\end{array}$ & Romania & \\
\hline 109. & Liesma Ose & University of Latvia & Latvia & \\
\hline 110. & Gunta Ošeniece & University of Latvia & Latvia & gunta.oseniece@lu.lv \\
\hline 111. & $\begin{array}{l}\text { Palmira } \\
\text { Peciuliauskiene }\end{array}$ & $\begin{array}{l}\text { Department of Education Science } \\
\text { Pedagogical University }\end{array}$ & Lithuania & palmira.p@post.skynet.lt \\
\hline 112. & Anita Petere & $\begin{array}{l}\text { Riga Teacher Training and } \\
\text { Educational management } \\
\text { academy }\end{array}$ & Latvia & anita.petere@rpiva.lv \\
\hline 113. & Kerstin Popp & University Leipzig & Germany & popp@rz.uni-leipzig.de \\
\hline 114. & Juris Porozovs & $\begin{array}{l}\text { Riga Teacher Training and } \\
\text { Educational management } \\
\text { academy }\end{array}$ & Latvia & juris.porozovs@rpiva.lv \\
\hline 115. & Gunita Praulite & $\begin{array}{l}\text { Riga Teacher Training and } \\
\text { Educational management } \\
\text { academy }\end{array}$ & Latvia & gunita.praulite@rpiva.lv \\
\hline 116. & Vēsma Priedīte & University of Latvia & Latvia & \\
\hline 117. & Jekabs Raipulis & $\begin{array}{l}\text { Riga Teacher Training and } \\
\text { Educational management } \\
\text { academy }\end{array}$ & Latvia & jekabs.raipulis@rpiva.lv \\
\hline 118. & Alona Rauckienė & Klaipėda University & Lithuania & alona.rauckiene@ku.lt \\
\hline 119. & Milena Remes & $\begin{array}{l}\text { University of Latvia, University } \\
\text { of Columbia }\end{array}$ & Latvia & mr2316@columbia.edu \\
\hline 120. & $\begin{array}{l}\text { Ernst-Christoph } \\
\text { Römer }\end{array}$ & & Germany & e.c.-roemer@web.de \\
\hline 121. & Susanne Römer & University Leipzig & Germany & s.roemer@uni.leipzig.de \\
\hline 122. & Zanda Rubene & University of Latvia & Latvia & zanda.rubene@lu.lv \\
\hline 123. & Ieva Rudzinska & $\begin{array}{l}\text { The Latvian Academy of Sport } \\
\text { Education }\end{array}$ & Latvia & ieva.rudzinska@inbox.lv \\
\hline 124. & Andris Rudzītis & $\begin{array}{l}\text { The Latvian Academy of Sport } \\
\text { Education }\end{array}$ & Latvia & \\
\hline 125. & Lūcija Rutka & University of Latvia & Latvia & lucija.rutka@lu.lv \\
\hline 126. & Jel̦ena Sargsjane & Daugavpils medicīnas koledža & Latvia & \\
\hline 127. & Eduard Saveliev & Zolitude Grammar School & Latvia & Eduard.Saveliev@mail.ru \\
\hline 128. & Oksana Shalajeva & $\begin{array}{l}\text { Latvia University of Agriculture, } \\
\text { Institute of Education and Home } \\
\text { Economics }\end{array}$ & Latvia & oxy@era2k.lv \\
\hline 129. & $\begin{array}{l}\text { Tamara } \\
\text { Shkolnikova }\end{array}$ & Riga Technical University & Latvia & tshk@inbox.lv \\
\hline 130. & Maruta Sīle & $\begin{array}{l}\text { Riga Teacher Training and } \\
\text { Educational management } \\
\text { academy }\end{array}$ & Latvia & maruta.sile@rpiva.lv \\
\hline 131. & $\begin{array}{l}\text { Gunta Siliņa- } \\
\text { Jasjukeviča }\end{array}$ & $\begin{array}{l}\text { Riga Teacher Training and } \\
\text { Educational management } \\
\text { academy }\end{array}$ & Latvia & gunta30@tvnet.lv \\
\hline
\end{tabular}




\begin{tabular}{|c|c|c|c|c|}
\hline 132. & Edita Slunjski & $\begin{array}{l}\text { University of Zagreb Faculty of } \\
\text { Humanities and Social Sciences }\end{array}$ & Croatia & edita.slunjski@zg.t-com.hr \\
\hline 133. & Sandra Smilga & $\begin{array}{l}\text { Business administration school } \\
\text { Turiba }\end{array}$ & Latvia & sandrasm@turiba.lv \\
\hline 134. & Rita Spalva & $\begin{array}{l}\text { Riga Teacher Training and } \\
\text { Educational Management } \\
\text { Academy }\end{array}$ & Latvia & rita.spalva@rpiva.lv \\
\hline 135. & $\begin{array}{l}\text { Christopher } \\
\text { Spencer }\end{array}$ & $\begin{array}{l}\text { Blackpool and The Fylde College } \\
\text { of Further and Higher Education }\end{array}$ & UK & cspe@blackpool.ac.uk \\
\hline 136. & Jurijs Spigins & Latvian Academy of Music & Latvia & spigin@cool.lv \\
\hline 137. & $\begin{array}{l}\text { Dalia Marija } \\
\text { Stanciene }\end{array}$ & $\begin{array}{l}\text { Faculty of Pedagogy and } \\
\text { Psychology of Vilnius } \\
\text { Pedagogical University }\end{array}$ & Lithuania & logos@post.omnitel.net \\
\hline 138. & $\begin{array}{l}\text { Rolandas } \\
\text { Stanionis }\end{array}$ & Klaipėda University & Lithuania & education.res@gmail.com \\
\hline 139. & $\begin{array}{l}\text { Kristina } \\
\text { Stankeviciene }\end{array}$ & Vilnius pedagogical university & Lithuania & kristina_vpu@yahoo.com \\
\hline 140. & Elita Stikute & University of Latvia & Latvia & elitastikute51@gmail.com \\
\hline 141. & Svetlana Surikova & University of Latvia & Latvia & svetlana.surikova@lu.lv \\
\hline 142. & Artis Svece & University of Latvia & Latvia & \\
\hline 143. & Mirjana Šagud & $\begin{array}{l}\text { Faculty of Teacher Education of } \\
\text { the University of Zagreb-local } \\
\text { branch in Petrinja }\end{array}$ & Croatia & Msagud1234@gmail.com \\
\hline 144. & $\begin{array}{l}\text { Vladimirs } \\
\text { Šibajevs }\end{array}$ & $\begin{array}{l}\text { Bērnu un jauniešu centrs '’IK } \\
\text { Auseklis"' }\end{array}$ & Latvia & bjcauseklis@riga.lv \\
\hline 145. & $\begin{array}{l}\text { Aldona Lucija } \\
\text { Tarasoniene }\end{array}$ & Vilnius pedagogical university & Lithuania & iul@vpu.lt \\
\hline 146. & Anna Tatarinceva & $\begin{array}{l}\text { Transport and Telecommunication } \\
\text { Institute, }\end{array}$ & Latvia & A_tatarinceva@inbox.lv \\
\hline 147. & Karmen Trasberg & University of Tartu & Estonia & karmen.trasberg@ut.ee \\
\hline 148. & Jel̦ena Treijere & & Latvia & \\
\hline 149. & Sarmīte Tūbele & Latvijas Universitāte & Latvia & sarmite.tubele@lu.lv \\
\hline 150. & Ligita Umbraško & Daugavpils medicīnas koledža & Latvia & \\
\hline 151. & Inga Vanaga & University of Latvia & Latvia & \\
\hline 152. & Žermēna Vazne & $\begin{array}{l}\text { Latvian Academy of Sport } \\
\text { Education }\end{array}$ & Latvia & z.vazne@e-teliamtc.lv \\
\hline 153. & Rasma Vīgante & University of Latvia & Latvia & rasma.vigante@lu.lv \\
\hline 154. & Elita Volāne & $\begin{array}{l}\text { Riga Teacher Training and } \\
\text { Educational management } \\
\text { academy }\end{array}$ & Latvia & elita.volane@rpiva.lv \\
\hline 155. & Lidija Vujičić & $\begin{array}{l}\text { University of Rijeka, Faculty of } \\
\text { Teacher Education Rijeka }\end{array}$ & Croatia & lidija@ufri.hr \\
\hline 156. & $\begin{array}{l}\text { Jel̦ena } \\
\text { Zaščerinska }\end{array}$ & University of Latvia & Latvia & $\begin{array}{l}\text { yelenazascerinska@hotmail. } \\
\text { com }\end{array}$ \\
\hline 157. & \begin{tabular}{|l|} 
Bronislavs \\
Zel̦cermans
\end{tabular} & $\begin{array}{l}\text { Pedagoǵiskais centrs } \\
\text { "Eksperiments" }\end{array}$ & Latvia & \\
\hline 158. & Alīda Zigmunde & $\begin{array}{l}\text { Institute of Humanities, Riga } \\
\text { Technical University }\end{array}$ & Latvia & azigmunde@web.de \\
\hline 159. & Juozas Zilionis & $\begin{array}{l}\text { Faculty of Pedagogy and } \\
\text { Psychology of Vilnius } \\
\text { Pedagogical University }\end{array}$ & Lithuania & ppf.dekanatas@vpu.lt \\
\hline 160. & Herbert Zoglowek & Finnmark University College & Norway & herbert@hifm.no \\
\hline 161. & Irēna Žogla & University of Latvia & Latvia & irena.zogla@lu.lv \\
\hline
\end{tabular}

